\title{
Recovery Plan for Wheat Blast Caused by Magnaporthe oryzae Pathotype Triticum
}

Update of June 4, 2013, Version

\author{
Barbara Valent, ${ }^{1,+}$ Giovana Cruppe, ${ }^{1}$ James P. Stack, ${ }^{1}$ C. D. Cruz, ${ }^{2}$ \\ Mark L. Farman, ${ }^{3}$ Pierce A. Paul, ${ }^{4}$ Gary L. Peterson, ${ }^{5}$ and Kerry F. Pedley ${ }^{5}$ \\ ${ }^{1}$ Department of Plant Pathology, Kansas State University, Manhattan, KS 66506 \\ ${ }^{2}$ Department of Botany and Plant Pathology, Purdue University, West Lafayette, IN \\ 47907 \\ ${ }^{3}$ Department of Plant Pathology, University of Kentucky, Lexington, KY 40546 \\ ${ }^{4}$ Department of Plant Pathology, The Ohio State University, Ohio Agricultural \\ Research and Development Center, Wooster, OH 44691
}

${ }^{5}$ United States Department of Agriculture-Agricultural Research Service (USDA-ARS), Foreign Disease-Weed Science Research Unit (FDWSRU), Fort Detrick, MD 21702

Accepted for publication 3 February 2021.

\section{Table of Contents}

Terms Used 183

Executive Summary............................................................. 183

I. Introduction ....................................................................... 184

II. Symptoms, Signs, Disease Cycle, and Pathogen Biology........... 189

III. Ecology and Epidemiology................................................ 193

IV. Monitoring and Detection............................................... 195

V. Response ...................................................................... 198

VI. Permits and Regulatory Issues ............................................ 199

VII. Impact on U.S. Economy and National Security ..................... 199

VIII. Mitigation and Disease Control ........................................... 200

IX. Research, Extension, and Education Priorities ...................... 203

X. References ..................................................................... 205

XI. Infrastructure and Experts ................................................ 211

XII. Web Resources ............................................................. 212

+ Corresponding author: B. Valent; bvalent@ksu.edu

This article is in the public domain and not copyrightable.

It may be freely reprinted with customary crediting of the source.

The American Phytopathological Society, 2021 
This recovery plan is one of several disease-specific documents produced as part of the National Plant Disease Recovery System (NPDRS) called for by Homeland Security Presidential Directive Number 9 (HSPD-9). The purpose of the NPDRS is to ensure awareness and availability of tools, infrastructure, communication networks, and capacity required to mitigate the impacts of high-consequence plant disease outbreaks and sustain crop production at levels that meet national needs.

Each disease-specific plan is intended to provide a brief primer on the disease and the threat it presents, assess the status of critical recovery components, and identify needs for disease management research, extension, and education. These recovery plans are not intended to be stand-alone manuals that address all of the many and varied aspects of plant disease outbreaks and all of the decisions that must be made and actions taken to achieve effective response and recovery. They are, however, documents that will enable USDA to guide further efforts directed toward plant disease recovery.

\section{Terms Used}

Magnaporthe oryzae (synonym of Pyricularia oryzae) is a plant-pathogenic fungus that is present worldwide as host-specialized populations called pathotypes, including the M. oryzae Oryza pathotype (MoO) causing rice blast in the United States and worldwide; the M. oryzae Triticum pathotype (MoT) causing wheat blast disease in South America, South Asia, and Africa; and the M. oryzae Lolium pathotype (MoL) causing gray leaf spot disease of the turf grasses perennial ryegrass and tall fescue, and blast disease on the forage/cover crop annual ryegrass in the United States, Japan, France, and China. For simplicity and clarity in this recovery plan, strains in the Oryza, Triticum, and Lolium pathotypes will be referred to as $\mathrm{MoO}, \mathrm{MoT}$, and MoL, respectively.

\section{Executive Summary}

Wheat blast is an explosive new fungal disease of wheat caused by a M. oryzae host-adapted subpopulation, known as the M. oryzae Triticum pathotype (MoT). Strains of the MoT pathotype are found in South America, South Asia, and Africa, but they have not yet been found in the United States. Wheat blast caused by the MoT fungus was first reported in Brazil in 1985 and subsequently spread to Bolivia, Paraguay, and Argentina in the 1990s and 2000s. The disease first appeared in Bangladesh in 2016 and in Zambia in the 2017-2018 rainy season. The MoT fungus is seedborne, and the most likely route for movement across oceans was though grain trade. Wheat head (spike) blast is the predominant form of the disease in the field, although foliar and stem blast also occur. The disease has proven difficult to control when weather conditions are conducive, often resulting in devastating yield and quality losses. The only currently effective resistance, contained in the $2 \mathrm{~N}^{\mathrm{V}} \mathrm{S}$ translocation from the wild wheat relative Aegilops ventricosa, confers partial resistance that is variable depending on the genetic background of the specific wheat variety. Fungicides are not fully effective in controlling wheat head blast if warm, humid weather occurs during the heading stage. A major disease management strategy in areas where the disease occurs involves timing the wheat planting date so that heading does not coincide with warm rainy weather. A "wheat holiday" strategy of not growing wheat for a few years has been implemented in South Asia to attempt to block further spread of the pathogen. However, MoT is clearly established in wheat, and now also in triticale, in Bangladesh. A climate suitability model for the United States, based on weather patterns from 1997 to 2006, indicated that all of U.S. soft red winter wheat (SRWW) and about half of the hard red winter wheat (HRWW) are at risk for wheat blast establishment.

Molecular diagnostics are needed to differentiate potential exotic MoT strains from the closely related U.S. Lolium pathotype (MoL) strains, which infect Lolium turf and forage grasses as primary hosts. Some native MoL strains can infect wheat as a second- 
ary host in controlled environment assays, although they are currently less aggressive toward wheat than MoT strains. An effective wheat blast diagnostic protocol has been developed and will be deployed through the National Plant Diagnostics Network to differentiate exotic MoT strains from native MoL strains. Availability of MoT diagnostics has enabled incorporation of official wheat blast surveys in the Animal and Plant Health Inspection Service (APHIS) National Cooperative Agricultural Pest Survey (CAPS) Program, beginning in 2021. Challenges to detection of wheat blast invasion in a timely manner include the superficial resemblance of bleached heads from wheat blast to symptoms of Fusarium head blight, which is widely established in the United States and occurs under similar environmental conditions. Extension materials and identification aids are essential to train individuals doing surveys to differentiate wheat blast from Fusarium head blight. Developing and deploying a U.S. wheat blast forecasting model is essential to focus surveys to locations and times with environmental conditions that favor blast disease.

Wheat blast disease is a moving target because the fungus is still evolving to become a better wheat pathogen. Recently isolated MoT strains are more aggressive toward wheat than previously isolated strains, and some recent MoT strains appear to have overcome $2 \mathrm{~N}^{\mathrm{v}} \mathrm{S}$-mediated resistance. Although wheat blast is mainly known as a head (spike) disease in the field, leaf blast is increasingly reported, and new epidemiological data support leaf blast as a source of inoculum potentiating head blast. Critical research priorities include continuing epidemiological studies to inform management strategies, including optimization of fungicide usage (e.g., rates and timing of application). Finding additional resistance genes is essential because most wheat varieties are susceptible, and even varieties with the partial $2 \mathrm{~N}^{\mathrm{v}} \mathrm{S}$-mediated head resistance are susceptible to some MoT strains. Development of global seed health strategies to detect and minimize movement of MoT-infected seed is critical to reduce further disease spread. The Triticum pathotype is highly adapted to cause disease on wheat and must not be allowed to establish and impact wheat production in the United States, a major wheat exporter. Additionally, the fungus is a threat to U.S. national security through its potential impact on global food security, international grain trade, and economic livelihoods in both politically stable and unstable regions of the world.

\section{Introduction}

Wheat blast is a recently emerged disease caused by the ancient grass pathogen Magnaporthe oryzae (synonym of Pyricularia oryzae), which has long plagued rice and subsistence millet crops worldwide (Valent et al. 2019, 2020; Zhang et al. 2016). Severe blast epidemics on wheat are caused by a separate $M$. oryzae lineage known as the Triticum pathotype (MoT), which is distinct from host-adapted populations causing blast on rice, finger millet, Italian (foxtail) millet, and other grasses. As wheat blast was spreading in Brazil in the late 1980s and early 1990s, a closely related M. oryzae lineage, the Lolium pathotype (MoL), emerged in the United States as a serious turf and forage grass pathogen, known as gray leaf spot. The MoT and MoL populations are closely related genetically and likely emerged from a common ancestor. However, MoT has adapted to cause severe epidemics on wheat as its primary host, and MoL has adapted to cause severe epidemics on Lolium ryegrasses as primary hosts. Some U.S. ryegrass isolates are able to infect wheat in controlled environment conditions and under field conditions (Farman et al. 2017; Mills et al. 2020; Rush and Carver 1973), but currently only the Triticum pathotype is causing devastating epidemics with up to $100 \%$ losses in wheat fields in areas where it occurs (Fig. 1). It is imperative that we prevent the Triticum pathotype from establishing in the U.S. wheat crop. 
Emergence, spread, and consequences. Seed transmission of M. oryzae is well established (Cruz and Valent 2017; Faivre-Rampant et al. 2013; Urashima et al. 2004a), enabling spread to new geographic locations through movement of infected seed. Wheat production has decreased in countries where blast disease has established, due to a lack of effective control measures under favorable weather conditions (Ceresini et al. 2018; Mottaleb et al. 2018). Wheat blast was observed for the first time in 1985 in the Brazilian state of Paraná, with commercial wheat fields in six municipalities severely affected in this first report (Igarashi 1990; Maciel 2011). By 1986, the disease had spread throughout Paraná and into two surrounding states (Fig. 2), and it subsequently moved throughout Brazil (Cruz and Valent 2017; Igarashi 1990; Kohli et al. 2011). The extended El Niño-Southern Oscillation event from 1986 to 1988 resulted in warm, humid weather that favored disease. The widespread planting of susceptible wheat varieties lacking resistance gene $R w t 3$ in this new blast-conducive region likely fueled the epidemic (Inoue et al. 2017). Brazil abandoned a major goal to increase wheat production in their Cerrado region due to difficulties in controlling blast (Ceresini et al. 2018; Maciel 2011). Wheat blast was first reported in Bolivia in 1996 (Fig. 2), hampering an initiative begun in the early 1990s to attain self-sufficiency in wheat production (Mottaleb et al. 2018). Bolivian wheat production increased from 10,865 metric tons in 1989 to 120,414 metric tons in 1997 . However, production fell to 37,750 metric

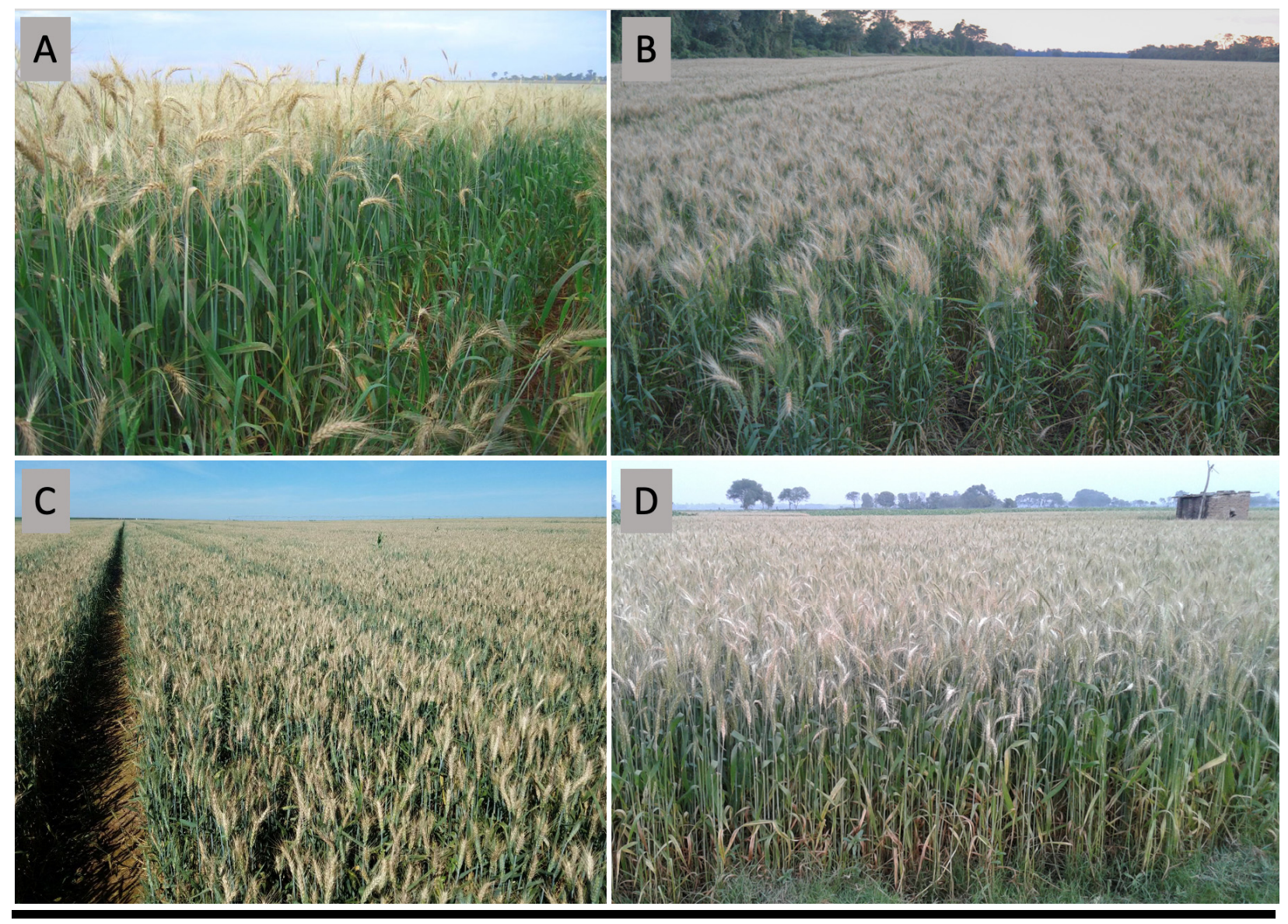

FIGURE 1

Wheat fields with $100 \%$ losses to blast. Heads were dead on still-green plants soon after their emergence. A, Near Londrina, Paraná, Brazil, in August 2009; B, in Bolivia in 2015; C, in Brazil in 2017; and D, in Bangladesh in 2016. The scale of perceived synchronous head infection without known leaf blast symptoms raised questions about the source of the inoculum for these large wheat fields. Photo A from Andreas von Tiedemann (Georg-August University Goettingen, Germany) \& Etienne Duveiller (CIMMYT, Mexico); B from Guillermo Isidoro Barea Vargas (Coperagro SRL, Bolivia); C from Jose Mauricio Fernandes (Embrapa, Brazil); and D from Paritosh Kumar Malaker, Bangladesh Wheat and Maize Research Institute, Bangladesh. 
tons in 1999 primarily due to blast. Wheat blast was reported in Paraguay in 2002 and in the province of Formosa in northeastern Argentina in 2007 (Cruz and Valent 2017). In 2009 in parts of northern Paraná, 100\% head infection observed over hundreds of hectares led to a total production loss (Fig. 1A), even though the leaves were still green and lacked obvious blast lesions (Duveiller et al. 2016). The large-scale epidemic in 2009 , which covered approximately $1 / 3$ of the total wheat-growing area in Brazil, began to focus global attention on the potential danger of wheat blast. In 2012, blast was detected in Buenos Aires Province, threatening important wheat-production areas of Argentina (Perelló et al. 2015).

In 2016, a widespread wheat blast outbreak was reported for the first time outside of South America (Fig. 1D), in eight districts (states) in Bangladesh (Malaker et al. 2016). Genome analyses indicated that a single MoT strain had been introduced from South America (Islam et al. 2016; Malaker et al. 2016), presumably through import of contaminated grain. This first wheat blast outbreak affected 15,000 ha (3.5\% of the total wheat area) (Mottaleb et al. 2018). Wheat blast occurred again in 2017 and spread to two new districts, despite weather that was not conducive for disease. Wheat production in Bangladesh dropped from 62,763 ha in 2016 to 14,238 ha in 2017. Bangladesh and regions of India bordering Bangladesh implemented "wheat holidays," in which growers stopped growing wheat for 2 to 3 years with the goal to eradicate the pathogen from

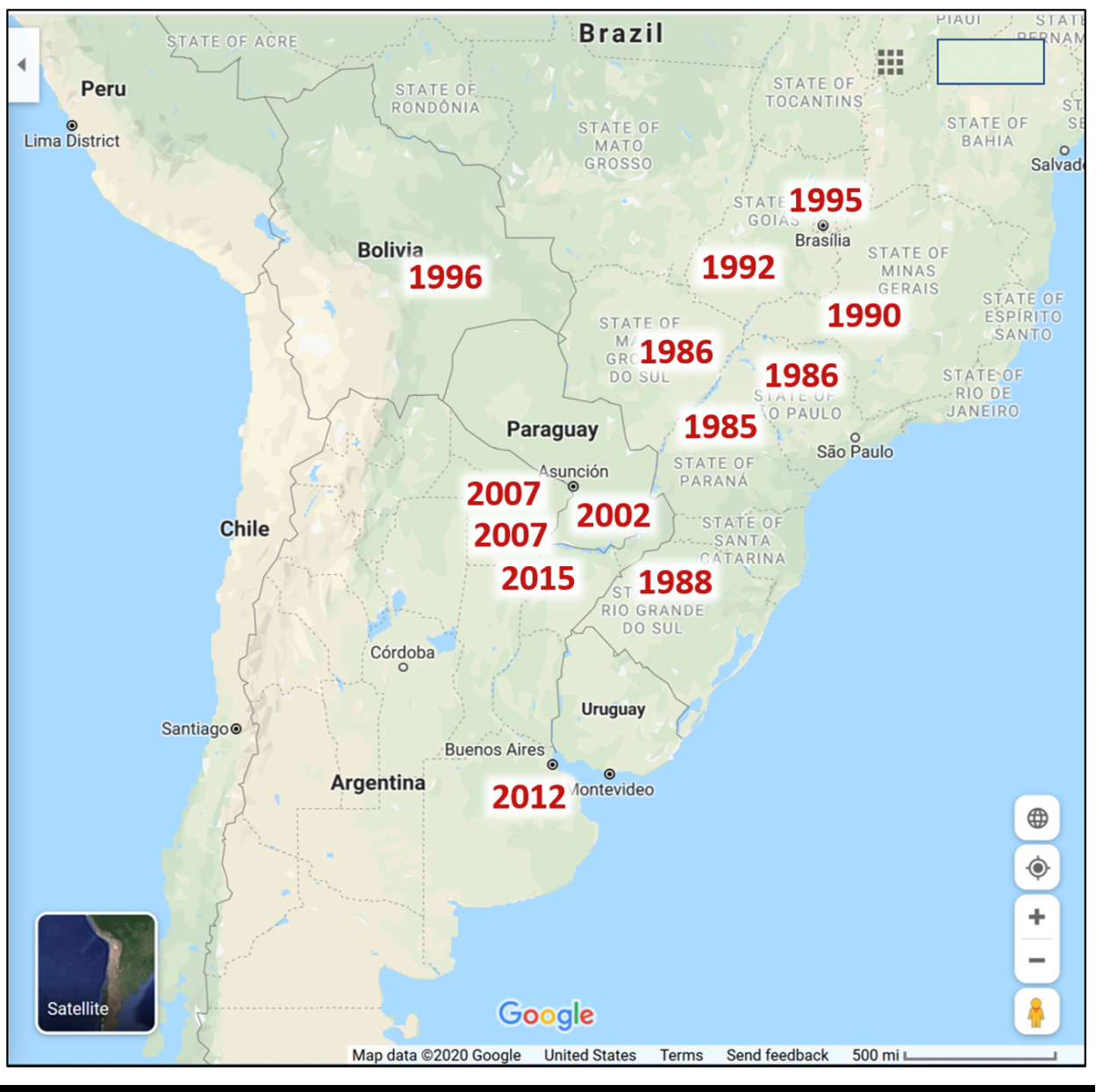

FIGURE 2

Timing of spread of wheat blast in South America after the initial report in Brazil in 1985 (Cruz and Valent 2017; Igarashi 1990). The disease was first reported in Bolivia in 1996, in Paraguay in 2002, and in Argentina in 2007. Epidemics in South America are associated with the warm, wet El Niño weather pattern. Wheat blast occurred beyond South America in Bangladesh in 2016 and in Zambia in 2017-2018. 
the region (Mottaleb et al. 2019). However, MoT is still occurring in wheat, and it also caused serious triticale blast in Bangladesh in 2019 (Roy et al. 2020). In addition, it was recently reported that wheat blast caused by MoT occurred on rain-fed wheat in Zambia during the 2017 to 2018 rainy season, establishing a foothold for this disease in Africa (Tembo et al. 2020).

Aggressive MoT isolates form a distinct lineage closely related to native MoL isolates. Strains of $M$. oryzae collectively infect $>50$ grass species, including cereal crops, turf, forage, and wild grasses. However, expanded lineages, known as pathotypes, have evolved and adapted to cause epidemics on primary host crops that are grown in monoculture over wide regions (Gladieux et al. 2018; Kato et al. 2000; Peng et al. 2019; Tosa et al. 2004). Within M. oryzae (Fig. 3), MoT is relatively distant from the Oryza pathotype (MoO) adapted for infecting rice (Oryza sativa), the Eleusine pathotype (MoE) adapted for infecting finger millet (Eleusine coracana), and the Setaria pathotype (MoS) adapted for infecting foxtail (Italian) millet (Setaria italica). The ancient blast diseases on rice, finger millet, and foxtail millet are still the most

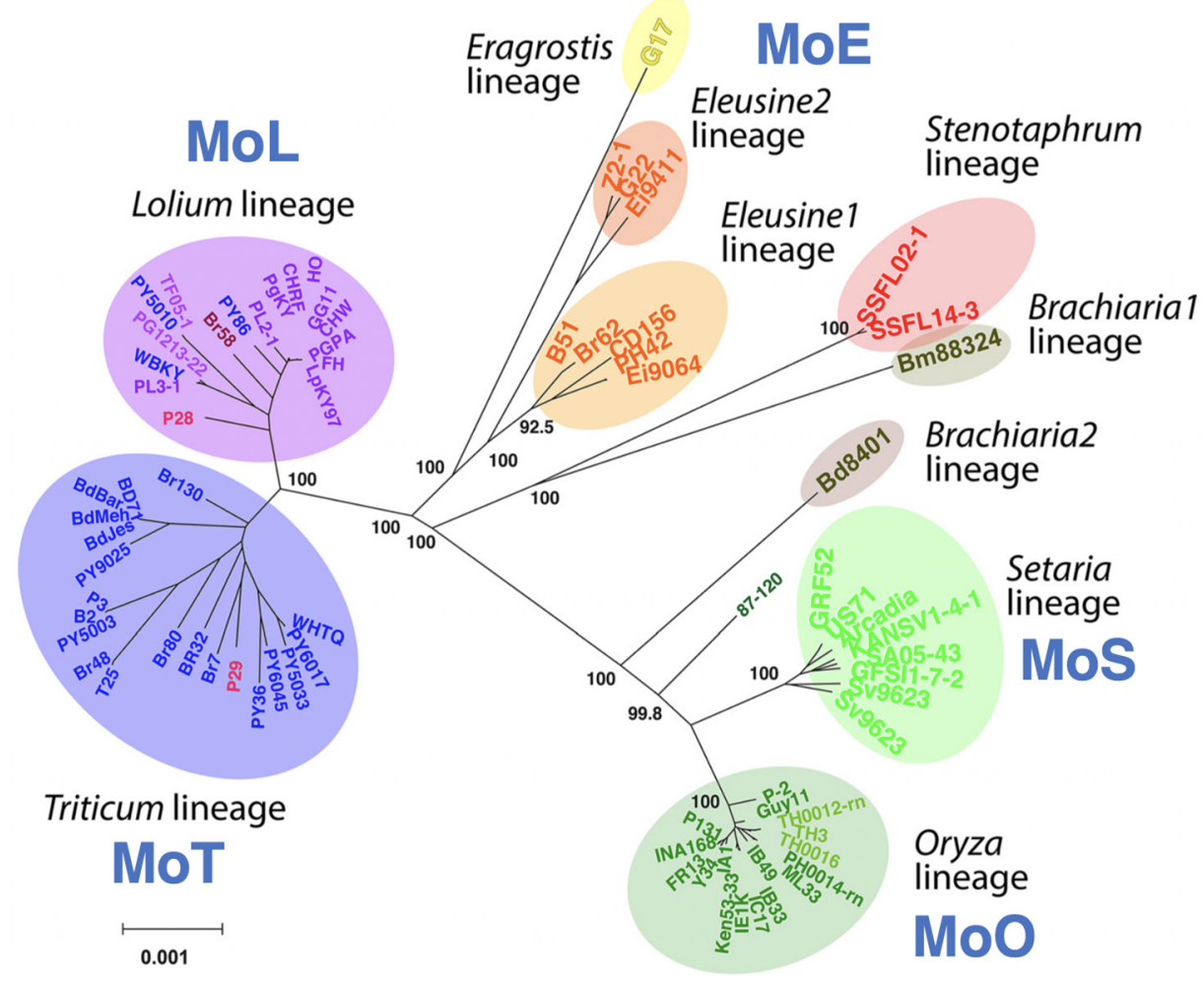

Hosts of origin (tip colors)

$\begin{array}{llll}\text { Lolium } & \text { Avena } & \text { Hordeum } & \text { Stenotaphrum } \\ \text { Festuca } & \text { Triticum } & \text { Setaria } & \text { Eragrostis } \\ \text { Bromus } & \text { Oryza } & \text { Brachiaria } & \text { Eleusine }\end{array}$

\section{FIGURE 3}

Phylogenomic tree showing host-adapted pathotypes (lineages) of Magnaporthe oryzae based on single nucleotide polymorphisms (SNPs per kilobase of unique DNA sequence) obtained through whole-genome sequencing. Isolate names are color coded according to the host from which they were isolated in the field. Host of origin is usually, but not always, indicative of the pathotype of the strain. Note that MoT strains occur in South America, South Asia, and Africa, but they have not yet been identified in the United States. The closely related MoL strains have spread throughout the United States since the new turfgrass disease gray leaf spot was identified in Pennsylvania in 1991. Adapted from Figure 3 in Gladieux et al. (2018). 
important diseases of these food crops (Manyasa et al. 2019; Takan et al. 2012; Wang and Valent 2009). In contrast, MoT is closely related to the MoL pathotype, which was first found on annual ryegrass and tall fescue forages in Louisiana and Mississippi in 1971 (Bain et al. 1972; Carver et al. 1972) and on perennial ryegrass turf in Pennsylvania in 1991 (Landschoot and Hoyland 1992). Gray leaf spot has since spread across the United States (Harmon and Latin 2005; Pedersen et al. 2000; Wong 2006) and moved into Japan, Europe, and China, presumably via infected seed (Milazzo et al. 2019; Tosa et al. 2004; Xue et al. 2017). Primary hosts for native MoL strains are perennial ryegrass (Lolium perenne), annual ryegrass (Lolium multiflorum), and tall fescue (Festuca arundinacea), which are turf and forage crops in the United States.

Genetic analyses of host specificity in M. oryzae. Genetic analyses of both $M$. oryzae and various host plants have shown that pathogen avirulence $(A V R)$ genes and corresponding host resistance $(R)$ genes are major determinants of the interaction between $M$. oryzae and different hosts, at both the rice and wheat variety levels and the host genus level (Tosa et al. 2016; Valent et al. 1991; B H. Wang et al. 2017). Specifically, $A V R$ genes in the pathogen encode secreted effector proteins that are recognized by the corresponding $R$ gene products, triggering resistance. More than 100 major rice $R$ genes have been identified to control blast, and 38 of these have been characterized at the molecular level. For the rice blast fungus, $13 \mathrm{AVR}$ genes have been molecularly identified, including 11 corresponding to characterized $R$ genes (B H. Wang et al. 2017). However, the rice blast fungus is still hard to control due to its ability to rapidly mutate or lose $A V R$ genes, thereby defeating deployed $R$ genes (Chuma et al. 2011). Research has been focused on mechanisms of effector gene variability in the fungus (Peng et al. 2019; X. Wang et al. 2017).

Several $A V R$ gene $/ R$ gene interactions have been shown to control specificity at the host genus level (Cruz and Valent 2017). Indeed, loss of an $A V R$ gene/ $R$ gene interaction apparently played a key role in emergence of wheat blast in Brazil (Inoue et al. 2017). Specifically, wheat varieties planted before the 1980 s contained the $R$ gene $R w t 3$, which corresponded to $A V R$ gene $P W T 3$ in MoL strains, blocking them from infecting wheat. In the $1980 \mathrm{~s}, r w t 3^{-}$wheat varieties lacking the $R$ gene were planted in a new blastconducive region in Brazil during a prolonged period of wet, warm El Niño-fueled weather (Igarashi 1990). Subsequent mutation to loss of PWT3 function allowed the emerging MoT population to cause disease on all wheat varieties.

Multiple studies suggest that wheat blast could establish in the United States through a second host jump/adaptation cycle from native MoL strains, as apparently occurred in Brazil (Inoue et al. 2017). Some U.S. MoL strains have been isolated from blastaffected wheat in the field (Carver et al. 1972; Farman et al. 2017). Wheat plants interplanted with ryegrass during the 1971 forage ryegrass epidemic in Louisiana were also infected by M. oryzae (Rush and Carver 1973). In 2011, a native MoL strain was isolated from a single blasted wheat head in a University of Kentucky experimental plot in Princeton, Kentucky, during a period of unusually warm, wet weather in May (Farman et al. 2017; Fernandes et al. 2017). Subsequent scouting failed to identify more blasted wheat heads, although a subsequent outbreak of Fusarium head blight (FHB) would have complicated identification. Numerous U.S. wheat varieties, including SRWW varieties, are susceptible to infection by some U.S. MoL strains in controlled environment assays (Mills et al. 2020). Mills et al. (2020) investigated combinations of temperature and high relative humidity duration on wheat head blast severity caused by a U.S. MoL strain, and they found that epidemiology of MoL-incited wheat blast appears similar to MoT-incited blast. However, comparative assays showed that tested MoL strains were less aggressive toward wheat than MoT strains, in terms of both slower disease progression and lower levels of disease severity (Gary Peterson, ARSFDWSRU, and Giovana Cruppe, Kansas State University [KSU], unpublished results). 


\section{Symptoms, Signs, Disease Cycle, and Pathogen Biology}

Symptoms and signs. The wheat blast pathogen can infect all above-ground parts of the wheat plant, but head infection is the most common symptom in the field. Infection of the stem at the base of the head (rachis) causes the entire head above the infection site to become bleached and die (Fig. 4A to C). Individual spikelets can also be infected without killing the entire head (Fig. 4D and E). Heads infected early during heading produce shriveled seeds or none at all, but heads with late infection can produce healthy-appearing seed that are infected by the fungus. Macroscopic symptoms from head blast closely resemble those from FHB but are distinguishable by the orange color of the Fusarium macroconidia when sporodochia are present (Fig. 4F).

Wheat leaf blast was reported soon after the disease was first recognized in Brazil (Cruz and Valent 2017; Igarashi 1990), but leaf symptoms were rarely reported after that. However, lesions on leaves and stems have been increasingly reported in commercial wheat fields in Bolivia over the last decade (Fig. 5). More recently, increasing observations of leaf lesions in Brazil have convinced at least one seed company to begin breeding for resistance at both the head and seedling stages (Paulo Kuhnem, Biotrigo Genetica, Brazil, personal communication). Epidemiological studies are increasingly supporting importance of leaf blast in the field (Cruz et al. 2015; Fernandez-Campos et

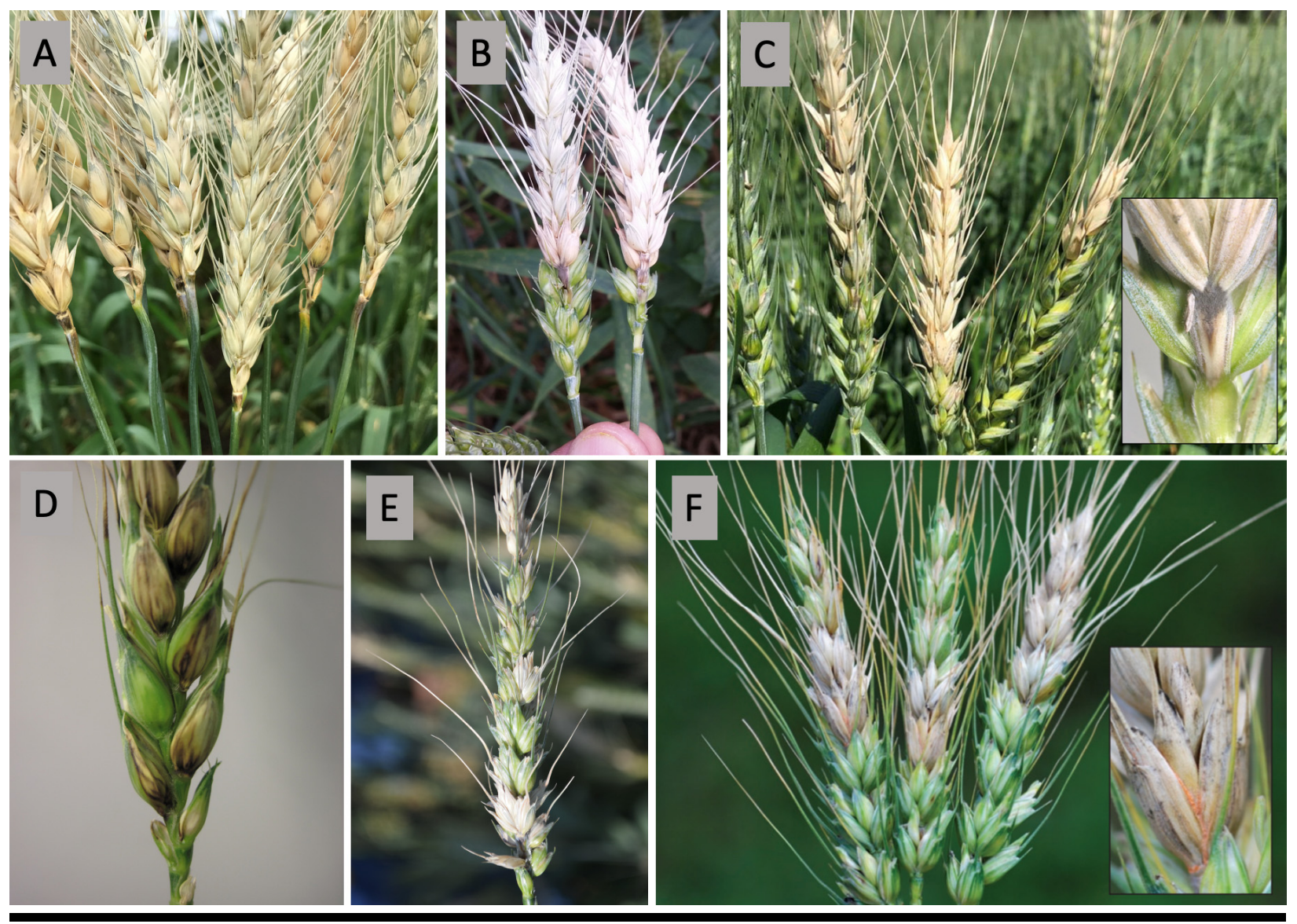

FIGURE 4

Wheat head blast symptoms compared with Fusarium head blight (FHB). A, Stem infection at the base of the head results in bleaching and death of the entire head. Note that the stem can appear healthy or can appear darkened. B and C, Stem infection internal to the head results in death of all head tissue above the point of infection. Note that the gray fungus is typically not visible until spikelets are removed just below the point of bleaching (B and inset in $C$ ). $\mathbf{D}$ and $\mathbf{E}$, Individual spikelets can be infected. In D, spray inoculation of newly emerged heads has resulted in independent infection of all but one spikelet. In E, field infection resulted in three independent infection points. $\mathbf{F}$, FHB infection is macroscopically similar except for the orange color of the fungus (inset), Fusarium graminearum, that is sometimes seen on FHB-infected heads. Photos A to C and E from Guillermo Isidoro Barea Vargas (Coperagro SRL, Bolivia); D reproduced from Cruz et al. (2016a); and F from Erick De Wolf, KSU (De Wolf, 2019). 
al. 2020; Gongora-Canul et al. 2020; Mills et al. 2021). Leaf and other lower canopy symptoms, when present, distinguish wheat blast from its look-alike disease FHB.

Wheat leaf lesions in the field resemble lesions on rice, including small dark brown spots without light centers (type 1, Fig. 5A), which fail to sporulate and represent a macroscopically visible resistance reaction (Valent et al. 1991). Susceptible lesions are typically eye-spot or spindle-shaped with light tan centers, often with dark brown margins and/or chlorotic halos (Fig. 5A and B). These lesions can range in size from small type 2 lesions ( $\sim 1 \mathrm{~mm}$ in length) up to a maximum-sized type 5 lesions ( 5 to $10 \mathrm{~mm}$ ), depending on pathogen strain aggressiveness and susceptibility of the host (Fig. 5A). Sporulating lesions appear gray from the color of hyphae and conidiospores (Fig. 5A and B); after spore dispersal, lesion centers are tan or straw-colored (Fig. 5C). Lesions on lower-canopy senescent leaves typically blend in with the senescent tissue unless they are producing gray conidia (Fig. 5D). Typical lesions can occur on lower stems (Fig. 5E). Sporulation potential for individual lesions correlates with the relative area of the light tan region (the sporulating region) inside the darker brown margins, with the largest lesions representing the most susceptible interactions (Valent et al. 1991). Although not studied in wheat, large leaf lesions in rice can produce tens of thousands of spores per night over a period of 20 days (Kato 1974). Rice seedling and leaf blast, together with leaf collar and stem node blast, are reported to provide inoculum for neck and panicle blast (Kato 1974). For rice, the youngest (still expanding) leaves are more susceptible than mature leaves (Kato 1974), but the opposite appears true for both wheat (Cruz et al. 2015) and perennial ryegrass (Moss and Trevathan 1987).

The disease cycle. The disease cycle is well-studied for rice blast (Oliveira-Garcia and Valent 2015; Wilson and Talbot 2009), and wheat blast and gray leaf spot appear to have similar cycles. The hallmark of the blast fungus is diagnostic pyriform conidia that give rise to the anamorph species name Pyricularia. Each conidium has three cells (Fig. 6A and B), with a single nucleus per cell. All nuclei in a conidium are derived through mitosis from a single nucleus; consequently, a fungal strain can be purified by
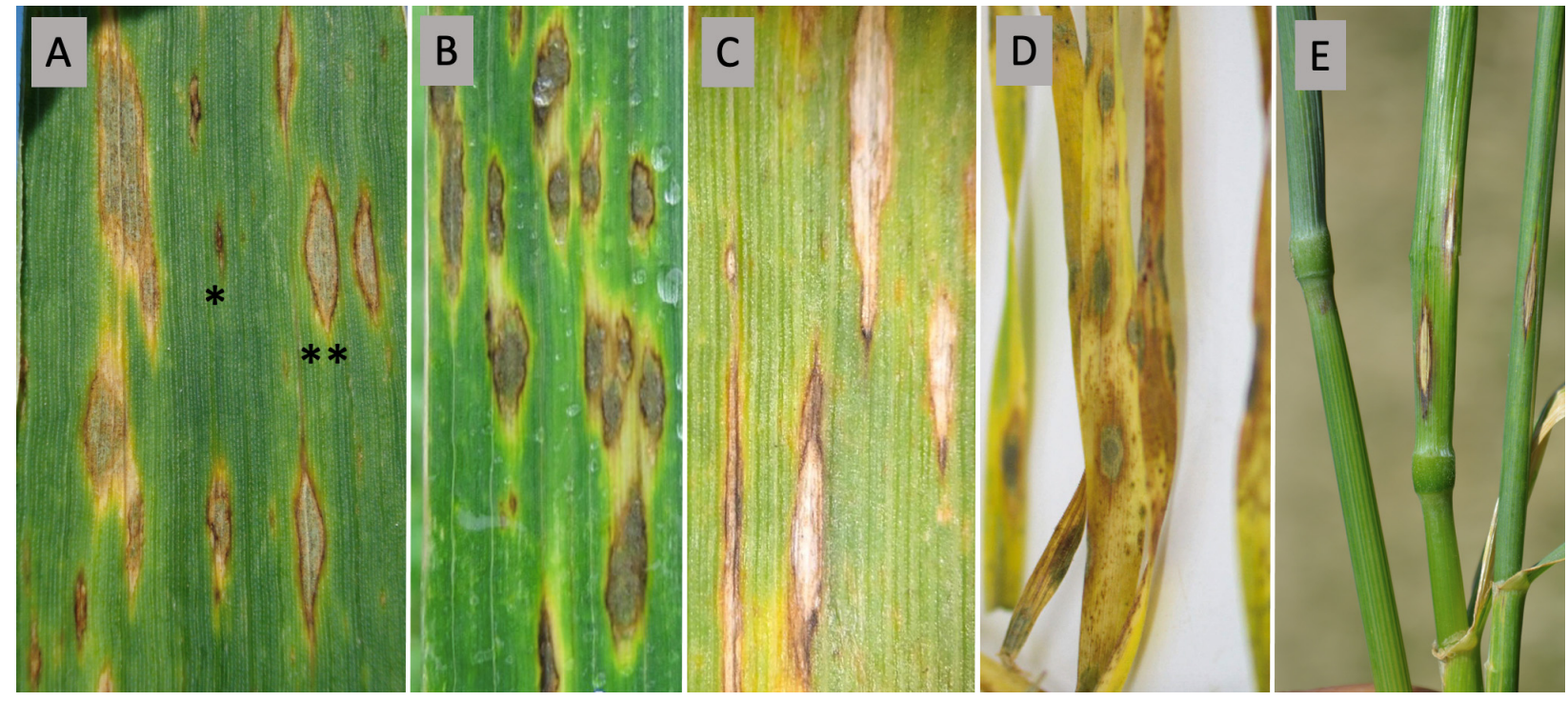

\section{FIGURE 5}

Lesions can occur on the leaves and lower stems of highly susceptible wheat cultivars in the field. A, Gray sporulating spindle-shaped lesions showing various sized lesions ranging from type $1\left({ }^{*}\right)$ resistance responses to type $5(* *)$ maximum-sized, fully susceptible lesions for a particular host variety. B, Sporulating irregular-shaped lesions resulting from multiple, coalescing infection points, here surrounded by distinct chlorotic halos that often occur. C, Lesions after spore release show the tan centers. D, Sporulating lesions on older senescent tissues. Lesions may not be distinguishable on senescent tissue unless they produce conidia, as shown here. E, Non-sporulating spindle-shaped lesions on lower stems. Photos A, B, C, and E show field samples. Photos A, C, and E from Guillermo Isidoro Barea Vargas (Coperagro SRL, Bolivia); B from Javier Toledo (Agripac Boliviana, Bolivia); and D from Cruz and Valent (2017). 
isolation of a single spore. M. oryzae appressoria can form and penetrate any aboveground plant tissue at any host developmental stage. This represents a major difference from FHB, for which head infection is limited to anthesis. The melanin layer in the cell wall of the appressorium is essential for this cell to build up the very high turgor pressure required to puncture the outer plant surface and gain access to host tissue (Fig. 6C). Therefore, fungicides that inhibit melanin biosynthesis (tricyclazole, pyroquilon, phthalide, and carpropamid) are effective in controlling blast diseases. Pressure buildup requires immersion of the appressorium in water (Howard and Valent 1996), explaining in part the requirement for standing water from rain or dew on the plant surface for infection to occur. High humidity is also required for the release of conidia from conidiophores to reinitiate the disease cycle. The physiology of infected wheat tissue and effects on host photosynthesis have been studied extensively (Rodrigues et al. 2017).

Blast conidia are adapted for rapid penetration of host plants and not for persistence outside the host (Fig. 6C). Laboratory studies of appressorium formation have shown that conidia lose ability to produce appressoria after several days at room temperature. Conidia appear packed with nutrients that are recycled via autophagy to power appressorial-mediated physical penetration of the host surface. After soaking for $>30 \mathrm{~min}$, drying of conidia from both rice and wheat isolates inhibits their ability to germinate and form appressoria (Cruz and Bockus, unpublished results; Kato 1974). On blast lesions in the field, wet conditions that release conidia from conidiophores also initiate their germination. To cause disease, conidia must immediately land on host tissue in order to form appressoria and penetrate back into a plant. For rice blast, most conidia
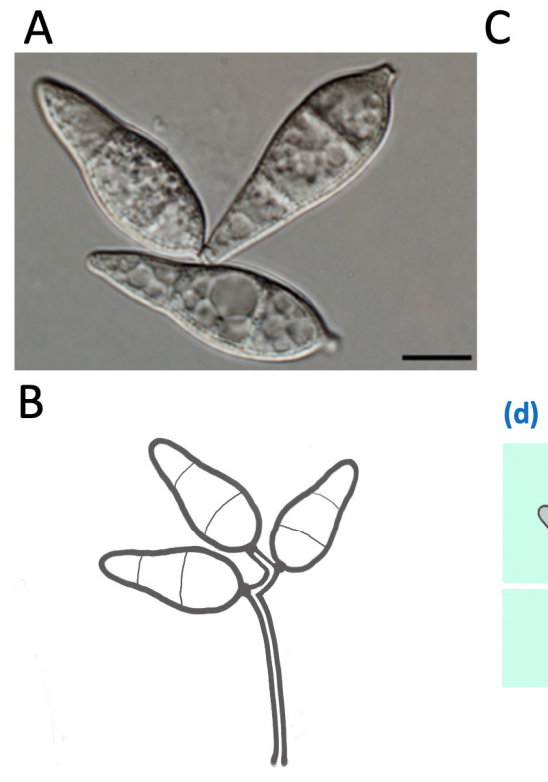

(e)

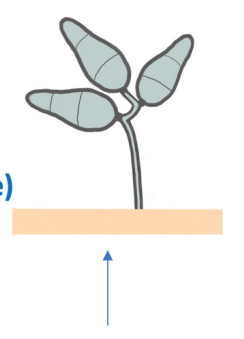

(d)

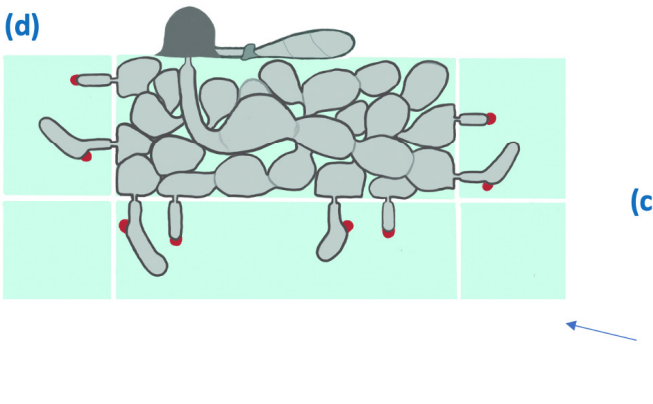

(a)

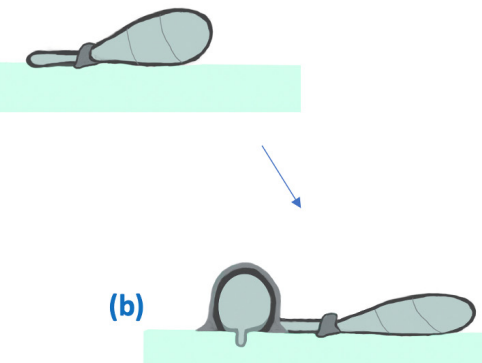

\section{FIGURE 6}

Blast disease cycle. A, Hyaline to pale gray, pyriform, asexual conidia are the major propagules of disease in the field. B, Conidia are borne sympodially on aerial conidiophores. C, Each conidial tip contains (a) "spore tip mucilage" that is released in wet conditions to glue the spore to the leaf surface. Each conidium grows as a specialized germ tube that senses the plant surface and differentiates an appressorium for host penetration. The appressorium (b) requires freestanding water and a thick layer of melanin (dark line in the appressorium cross section) to generate turgor pressure (80 times atmospheric pressure) to power mechanical force enabling the penetration peg to puncture the plant surface. Contents of conidia are redeployed into sealed appressoria via autophagy. Specialized invasive hyphae (c) colonize living epidermal cells while sealed inside a plant membrane compartment, which features the biotrophic interfacial complex (BIC, red) as the staging area where effectors are translocated across the plant plasma membrane into the plant cytoplasm. Invasive hyphae (d) colonize surrounding live plant cells, with each new hypha producing a BIC (red) to deliver effectors inside the cell. After colonizing host tissues for 4 to 5 days (e), macroscopic tissue death becomes visible and sporulation begins. A reproduced from Zhang et al. (2014); B and C from Barbara Valent, KSU. 
have been detected in the lower third of the canopy, although conidia have been detected kilometers away from fields (Kato 1974). Conidia from triticale can travel at least 1,000 $\mathrm{m}$ from the inoculum source (Urashima et al. 2007).

The sexual cycle, ascospores, and microconidia. The $M$. oryzae sexual cycle has not been observed in nature, but some isolates undergo sexual crosses in the laboratory (Yaegashi and Udagawa 1978). Wheat blast isolates from the 1980s and early 1990s showed high levels of sexual fertility (Cruz and Valent 2017; Orbach et al. 1996; Urashima et al. 1993), functioning as hermaphrodites and crossing to produce abundant viable ascospores (Fig. 7). Population analysis in Brazil indicated that MoT currently exhibits a mixed reproductive system in the field, with sexual reproduction followed by the local dispersal of asexual conidia (Maciel et al. 2014). Sexual fertility of early MoT strains contrasts with the infertility of most MoO field isolates and the mainly clonal asexual populations of rice pathogens in the field. Interfertility among strains of all the M. oryzae genus-specific pathotypes, including rare fertile rice pathogens, has
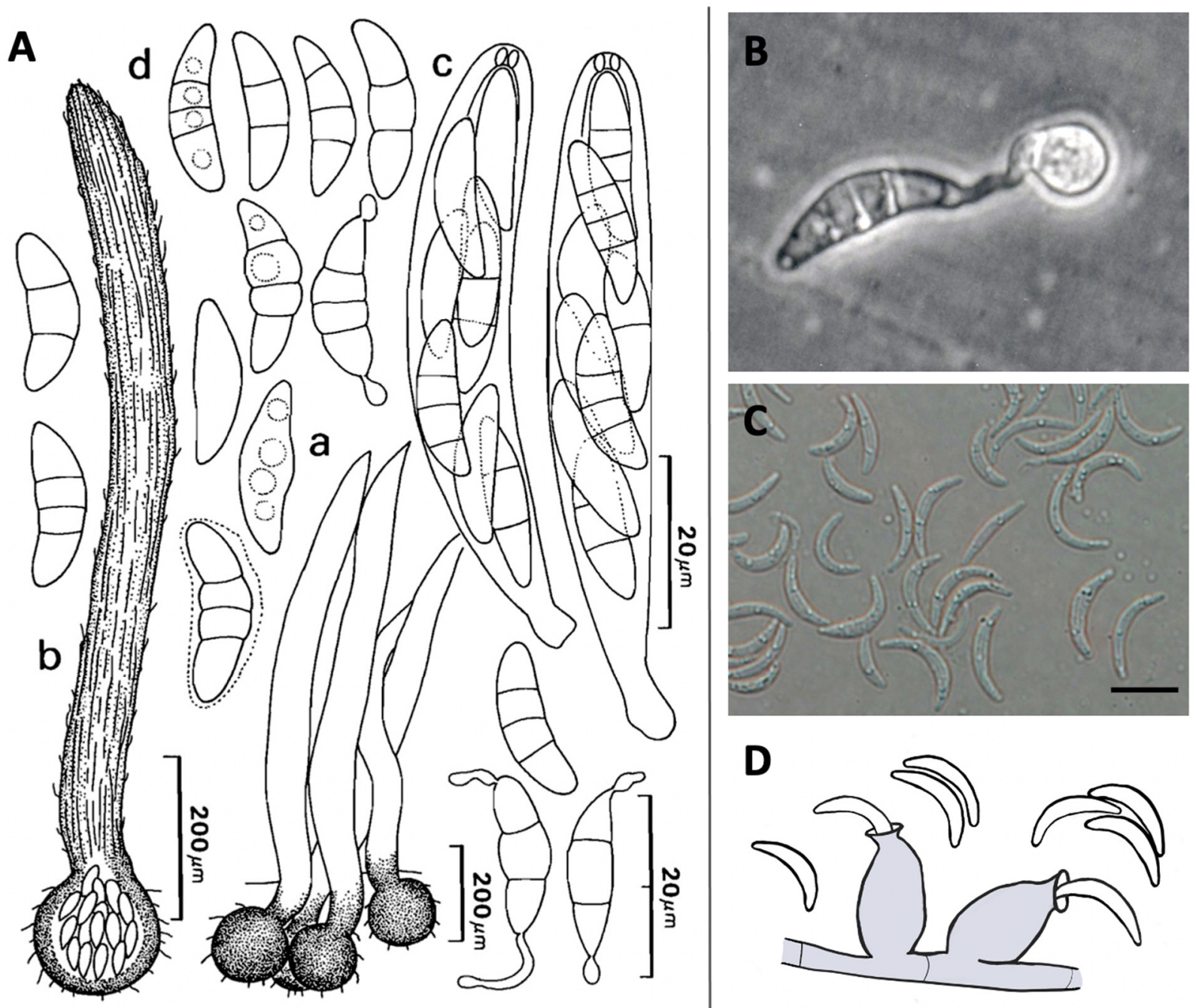

\section{FIGURE 7}

Spore types associated with sexual fertility in the heterothallic Ascomycete Magnaporthe oryzae. A, Drawing depicting features and sizes of $M$. oryzae sexual structures: $(a, b)$ perithecia in which meiosis occurs; $(c)$ asci containing two copies of each of the four products of a single meiosis; and (d) four-celled hyaline ascospores. B, Ascospores germinate and form appressoria similar to those formed by asexual conidia. C, Single-celled microconidia are associated with sexually fertile strains. Although microconidia can germinate and cause infection, their role in the disease biology is unknown. Scale bar $5 \mu \mathrm{m}$. D, Drawing depicting M. oryzae Phialophora-like, pigmented flask-shaped phialides from which microconidia (phialospores) emerge. A reproduced, by permission, from Yaegashi and Udagawa (1978); B and D from Barbara Valent (KSU); and C reproduced from Zhang et al. (2014). 
allowed the identification of multiple $A V R$ genes that control host specificity in this pathosystem (Inoue et al. 2017; Tosa et al. 2016; Valent et al. 1991).

M. oryzae is a heterothallic Ascomycete, class Pyrenomycete, that is associated with extensive host specialization at the host genus level and at the variety level within a crop species (Couch et al. 2005). Fully fertile strains are self-sterile hermaphrodites (functioning both as females and males), with compatibility for mating governed by alternate alleles of the mating-type locus MAT1. Ascospores are produced in unordered asci within perithecia with long necks (Fig. 7A) (Yaegashi and Udagawa 1978). Ascospores are hyaline and crescent-shaped, with four cells, each containing a single mitotically derived nucleus. Perithecia produce asci within 2 to 3 weeks when strains of opposite mating types are incubated on oatmeal agar in the light at $\sim 20^{\circ} \mathrm{C}$ (Valent et al. 1991). Mature asci are extruded through the perithecial necks, and ascospores are released into a viscous liquid. Ascospores produce appressoria for plant penetration (Fig. 7B).

Sexually fertile $M$. oryzae isolates also produce small, crescent-shaped microconidia, $\sim 6 \mu \mathrm{m}$ in length and $\sim 0.7 \mu \mathrm{m}$ in width (Fig. $7 \mathrm{C}$ ). Microconidia are hypothesized to function as spermatia, but there is no evidence for this. Microconidia are produced from Phialophora-like flask-shaped phialides (Fig. 7D), but their role in M. oryzae field biology is still unknown (Chuma et al. 2009; Kato et al. 1994; Zhang et al. 2014). The ability of fertile M. oryzae strains to produce microconidia from phialides is consistent with the fungus's close taxonomic relatedness to the phialideproducing root pathogens Magnaporthe poae and Gaeumannomyces graminis (Zhang et al. 2018). M. oryzae is reported to infect roots in laboratory studies, using common tactics of its root-invading relatives including forming melanized runner hyphae on roots as well as microsclerotia (Marcel et al. 2010; Sesma and Osbourn 2004). This previously unknown ability for hyphal plasticity may suggest unknown field biology for $M$. oryzae. For example, long-term resting structures have not been identified for the blast fungus.

\section{Ecology and Epidemiology}

Disease-conducive weather. Blast epidemics with severe crop losses occur in some years but not others, depending on occurrence of warm weather with high humidity (Urashima et al. 1993). In South America, severe wheat blast epidemics (1987, 1997, 2002, 2009, 2015) correlate with occurrence of the El Niño-Southern Oscillation (Kohli et al. 2011; Valent et al. 2020). Wheat blast epidemics were reported to follow several days of continuous rains and temperatures from 18 to $25^{\circ} \mathrm{C}\left(64\right.$ to $\left.77^{\circ} \mathrm{F}\right)$ during flowering, followed by hot, sunny, and humid days (Kohli et al. 2011). Controlledenvironment studies indicate that the minimum temperature for infection is $10^{\circ} \mathrm{C}\left(50^{\circ} \mathrm{F}\right)$ and the maximum is $32^{\circ} \mathrm{C}\left(90^{\circ} \mathrm{F}\right)$, with an optimum between 25 and $30^{\circ} \mathrm{C}\left(77\right.$ and $\left.86^{\circ} \mathrm{F}\right)$ (Cardoso et al. 2008). Temperature optima between 25 and $30^{\circ} \mathrm{C}$ have also been reported for MoL isolates on both ryegrass and wheat (Mills et al. 2020; Moss and Trevathan 1987). High relative humidity from rain and/or dew are required for appressorial pressure build-up and host surface penetration, for conidiation, and for release of conidia from conidiophores (Alves and Fernandes 2006).

The question of whether the fungus could survive the colder temperatures during the U.S. winter is a critical consideration because it impacts how far north the disease could establish in the United States. The research community standard for permanent storage of the fungus is freezing dried mycelium in filter papers or freezing dried infected leaf tissue. The fungus can survive over three decades with many freeze-thaw cycles under these conditions (B. Valent, personal communication). In a controlledenvironment experiment using naturally infected residue from Bolivia, survival of MoT conidia varied considerably when dry or moistened residue was exposed to several freeze-thaw treatments (i.e., freeze at $-15^{\circ} \mathrm{C}$ for $23 \mathrm{~h}$ and then thaw at $22^{\circ} \mathrm{C}$ for $1 \mathrm{~h}$ ) (Fischer 2016). Consistent with permanent storage techniques, numbers of viable MoT 
conidia in the dry residue were not significantly affected by the freeze-thaw treatments. In contrast, MoT survival in moistened residue was reduced by $66 \%$ when exposed to five freeze-thaw cycles compared with the control (Fischer 2016). Experiments in Brazil demonstrated that MoT did not survive more than 5 months in crop residue contained in nylon bags distributed in ryegrass fields (Pizolotto et al. 2019). The moisture status of crop residue appears to have a major effect on fungal viability.

Inoculum sources. Three potential inoculum sources could provide MoT conidia early in the season, which, under conducive conditions, would provide time for foliar disease development and a higher pathogen population at the heading stage. Conidia might originate from any or all of these sources:

Seed. Planting of MoT-infected seed has been shown to result in seedling blast in laboratory studies (Cruz and Valent 2017; Faivre-Rampant et al. 2013), suggesting contaminated seed as a source of inoculum of lower canopy leaves in the field. Sporulation has been observed in lower senescent wheat leaves in the field, including at the time of heading, providing a potential in-field source of conidia for head inoculation (Cruz et al. 2015).

Crop residue. Information on MoT survival on crop residue under field conditions is limited. A study conducted in Brazil demonstrated that MoT in inoculated plant tissue did not survive more than 5 months when incubated in fields inside nylon bags (Pizolotto et al. 2019). The authors concluded that crop residue would probably not be a source of inoculum for wheat blast in the subsequent spring wheat season in Brazil, which is rarely sown within a 5-month period. This is quite different from the winter wheat season in the United States, which extends from September-November to JuneJuly, with a fallow period of less than 5 months between successive crops. Another group studied sporulation in naturally infected rice panicles when incubated in rice fields above or inside a rice mulch layer or buried in the soil in Madagascar (Raveloson et al. 2018). High sporulation capacity persisted 10 to 18 months on or in rice residue but was rapidly lost in panicles buried in the soil to a depth of $10 \mathrm{~cm}$. Studies with MoL have shown that infected debris can contribute inoculum for the subsequent season (Harmon and Latin 2005).

Alternative hosts. Strains of individual pathotypes are highly aggressive in causing damaging epidemics on their primary hosts, but many strains can also cause disease symptoms on and be isolated from alternative secondary hosts (Fig. 3). On primary hosts, most appressorial penetration sites result in large sporulating lesions, whereas on secondary hosts, fewer functional appressoria result in lesions that are usually restricted in size and sporulation capacity (Heath et al. 1990; Tredway et al. 2005). Blast lesions on weeds and other secondary hosts could serve as a reservoir and a potential source of inoculum for nearby wheat fields. However, the field potential for cross-infectivity of the different host genus-adapted forms of $M$. oryzae is currently unclear because few studies address levels of pathogen aggressiveness differentiating primary and secondary hosts. Many studies show that fungal isolates collected in nature generally belong to the pathotype specialized for the host genus from which they were collected (Couch et al. 2005; Gladieux et al. 2018; Tredway et al. 2005). However, cross infection does occur in the field. For example, strain P29 (Fig. 3, red) is a MoT strain isolated from a Bromus tectorum plant inside a heavily blast-affected wheat field under disease-conducive conditions in Paraguay. Therefore, isolation from a particular host plant is not a definitive indicator of pathogen pathotype.

Artificial inoculation experiments have indicated that wheat is susceptible to isolates from many weed species, including Alexandergrass (Brachiaria plantaginea), sourgrass (Digitaria insularis), crabgrass (D. sanguinalis), goosegrass (Eleusine indica), fountain grass (Pennisetum setaceum), Rhynchelytrum roseum, and knotroot foxtail (Setaria geniculata) (Tredway et al. 2005; Urashima et al. 2004a; Viji et al. 2001). Greenhouse/growth chamber inoculations suggest that MoT isolates are also pathogenic to triticale, barley, oats, black oats, common millet, corn, rye, and sorghum (Kohli et 
al. 2011; Urashima et al. 1993, 2004b, 2017). However, blast disease assays under controlled conditions are very sensitive to general plant health, fertilizer regime, and other conditions. Therefore, care must be taken when interpreting artificial inoculation studies. Probable secondary hosts for MoT include forage grasses that are commonly interplanted with wheat in the southeastern United States, including ryegrass, tall fescue, oats, and rye (Twidwell et al. 2019), but this needs further investigation.

Disease development and spread in time. Research is now beginning to fill gaps in understanding how wheat blast disease develops and spreads in time and space through infected fields. Widespread, seemingly synchronous bleaching and death of wheat heads on apparently healthy plants over vast areas (Fig. 1) led to the suggestion that wheat head blast was a monocyclic disease with inoculum arising from alternative hosts outside the fields (Pizolotto et al. 2019). However, identification of sporulating lesions on basal senescent leaves (Fig. 5D) during heading in the field suggested that leaf lesions could have provided inoculum for head blast development (Cruz et al. 2015). Multiple epidemiological studies at diverse field sites during four wheat seasons in South America quantified and compared the temporal rate of change in head blast intensity. All of these studies agreed that for both leaf and head blast disease the progress was best described with logistic models, which generally indicate polycyclic epidemics (Cruppe 2019; Fernandez-Campos et al. 2020; Gomes et al. 2019; GongoraCanul et al. 2020; Mills et al. 2021). Irrigated field trials during the 2017 Bolivian winter, conducted in nonconducive weather, showed that a single inoculation of seedlings at the three-leaf stage led to near 100\% head blast infection (Cruppe 2019). Genome analysis of the fungus isolated from diseased heads confirmed that they were infected with the inoculated strain. In this study, head symptoms increased from near zero to maximum intensity in a period of 13 to 21 days (Cruppe 2019; Gongora-Canul et al. 2020). In other inoculated field experiments at two locations during the 20182019 Bolivian summer, a polycyclic-like disease cycle was reported based on temporal disease dynamics of 10 varieties with varying levels of resistance (Fernandez-Campos et al. 2020). Natural infection experiments were performed in three distinct humidity zones in the Bolivian production region during the El Niño-fueled epidemic year 2015 (Mills et al. 2021). These experiments documented the impact of different rainfall patterns on head blast temporal dynamics. Head blast increased for 20 to 30 days before approaching a mean incidence of $100 \%$, and a mean severity of 60 to $75 \%$. At one location in which early rain days enhanced initial leaf blast intensity, survival analyses showed that increasing levels of leaf blast increased the probability of head blast severity reaching thresholds by day 21 after heading, indicating that leaf blast can impact head blast dynamics in the field (Mills et al. 2021). Additional studies are needed to define relative roles of in-field or external inoculum sources over a range of geographic locations and weather patterns.

\section{Monitoring and Detection}

Wheat blast has been included in the APHIS National CAPS Program, with official surveys beginning in 2021. A factor complicating rapid identification of wheat blast is that blast-affected heads resemble those with typical symptoms of FHB, a widespread disease in the United States (Fig. 4F). Consequently, wheat blast may be mistaken for FHB when it first appears in the field, unless wheat producers and extension specialists are trained to anticipate, recognize, and differentiate between the two diseases. In particular, training and close examination will be required for first responders to differentiate the FHB-type bleaching (Fig. 4F), which sometimes shows traces of orange to pink spore masses, from wheat blast-type bleaching (Fig. 4A to E), which is creamcolored with gray $M$. oryzae spore masses at the base of bleached spikelets. If microscopic examination of infected tissue does not reveal the gray pyriform conidia diagnostic for wheat blast, incubation of diseased tissue under high humidity might 
induce sporulation. However, recovering the blast fungus from leaf lesions that have already sporulated can be difficult. Also, the blast fungus is hard to recover from field samples if the tissue is too wet, because infected tissue pieces incubated with freestanding water on their surfaces will typically only yield saprophytic contaminants.

Two additional signs could alert surveyors that observed symptoms are wheat blast. First, leaves could be surveyed for the appearance of blast lesions. That should include close examination of the older senescent leaves for presence of gray fungal masses. Second, the time of disease onset and characteristic symptom development relative to crop growth stage could provide a clue. The blast fungus can invade head tissue and begin infection anytime between early heading (Feekes 10.5) and soft dough (Feekes 11.2). In contrast, F. graminearum infection typically occurs during anthesis (Feekes 10.5.1). It takes between 10 and 14 days after anthesis for the first symptoms (spots) of FHB to appear and between 18 and 21 days after anthesis (soft dough) for entire spikelets, and occasionally entire heads, to become fully bleached and discolored. Therefore, bleached heads before anthesis or between anthesis and watery ripe (Feekes 10.5.4) could indicate wheat blast. Of course, other factors may cause bleached heads, including take-all, frost damage, eyespot, or insect damage.

Diagnostics development and validation. Identifying diagnostic markers that differentiate MoT strains from the closely related MoL strains has been a challenge. One marker from the MoT3 locus (a retinol dehydrogenase gene) has been used for development of end-point and real-time PCR-based diagnostic assays (Pieck et al. 2017; Yasuhara-Bell et al. 2019). The USDA-APHIS Plant Protection and Quarantine Science and Technology (PPQ S\&T) Beltsville Laboratory (the primary U.S. Federal Plant Pathology accredited laboratory that conducts operational diagnostics for regulated plant pathogens), has validated the MoT3 assay and developed a workplan for deployment through the National Plant Diagnostic Network (Bienapfl et al. 2018; Stack et al. 2014). The MoT3 locus and POT2, an M. oryzae-specific transposon, were used to develop a loop-mediated isothermal amplification (LAMP) assay for specific MoT detection in field settings (Yasuhara-Bell et al. 2018). Protocols have been optimized for detecting seed-borne MoT in seed/grain shipments in laboratory studies, but these studies also point out the sampling challenges in detecting contamination of large grain lots (Kiyuna 2019). One study using recent isolates from Bangladesh reproduced the reported specificity of the MoT3 assay (Roy et al. 2020). Another laboratory in Bangladesh failed to reproduce MoT3 specificity (Gupta et al. 2019), but their results can be explained by technical issues and strain misidentification (Yasuhara-Bell et al. 2019). Based on the initial studies of 421 strains, one MoT strain from 1991 lacked the MoT3 sequence and two non-MoT strains contained the MoT3 sequence, resulting in acceptable false positive and false negative rates of $<0.005 \%$. It now appears that MoT and MoL genomes are admixtures of DNA inherited from several other host-specialized forms of M. oryzae through sexual crosses (M. Farman, University of Kentucky, unpublished data). This means that the current diagnostic probes, although having proven effective in identifying wheat blast to date, actually target sequences present in other poorly or, as yet, unsampled M. oryzae populations. Therefore, some false positives and false negatives are inevitable. A second MoT-specific diagnostic test has recently been reported (Thierry et al. 2020). Like MoT3, this test yields rare, nonspecific amplification from non-MoT strains, and it targets a locus contributed to MoT by an unsampled lineage that is different from the MoT3 source (M. Farman, University of Kentucky, unpublished data). This second locus would provide a complementary addition to the MoT diagnostic system, with the possibility of final, confirmatory tests being developed once the unknown donor population is finally characterized.

Climate suitability, risk, and forecasting models. Accurate prediction models are required for determining when and where to scout for wheat blast occurrence. An initial U.S. climate suitability study for wheat blast has been developed by comparing climate and weather in the United States (1997 to 2006) with conditions conducive for ryegrass 
blast in the United States and wheat blast in Brazil (Cruz et al. 2016b). Multiple days with freeze-thaw conditions were predicted to limit climate suitability by reducing fungal survival and inoculum build-up (Fig. 8A). With the chosen parameters, the climate would be adequate for maintaining MoT populations in $40 \%$ of the U.S. winter wheat production areas, comprising all of the SRWW area, primarily in the southeastern United States, and over half of the HRWW area (Fig. 8B). Soft white wheat grown in the Pacific Northwest is also at some risk according to this model. Probability of years suitable for outbreaks was greater than $70 \%$ in Louisiana, Mississippi, and Florida. In May of 2011, weather conditions allowed a MoL strain to infect a wheat head in Kentucky, but subsequent development of widespread FHB would have obscured any further blast infection. Updated models are needed, confirming impact from numbers of days with freeze-thaw conditions and taking climate change into account. Increasing global temperatures will undoubtedly increase the potential for overwintering and earlier development of $M$. oryzae diseases coincident with winter wheat production. There is also potential for the MoT population to adapt to cause disease in temperate climates, based on the current status of rice blast as a serious disease in temperate climates (Khush and Jena 2009; Orasen et al. 2000).

A risk corridor assessment (a quantitative pathway risk assessment) approach, based on actual trade records and practices, will highlight possible routes of MoT entry and establishment in order to focus monitoring efforts and surveillance locations (Cruz 2013). This approach was demonstrated through analysis of a known example. In 2010, U.S. livestock producers imported low-priced, low-quality wheat from Brazil following the major MoT outbreak in 2009. Grain was imported through the port of Wilmington, North Carolina. According to industry norms for ground transportation of grain, kernels were likely blown from uncovered trucks in areas with conditions favorable for MoT establishment during transport to feed mills and feedlots. Abundant wheat fields within range of infected grain provided a high risk of introduction and establishment along these trucking corridors. Similar model results may be used to inform regulatory policy
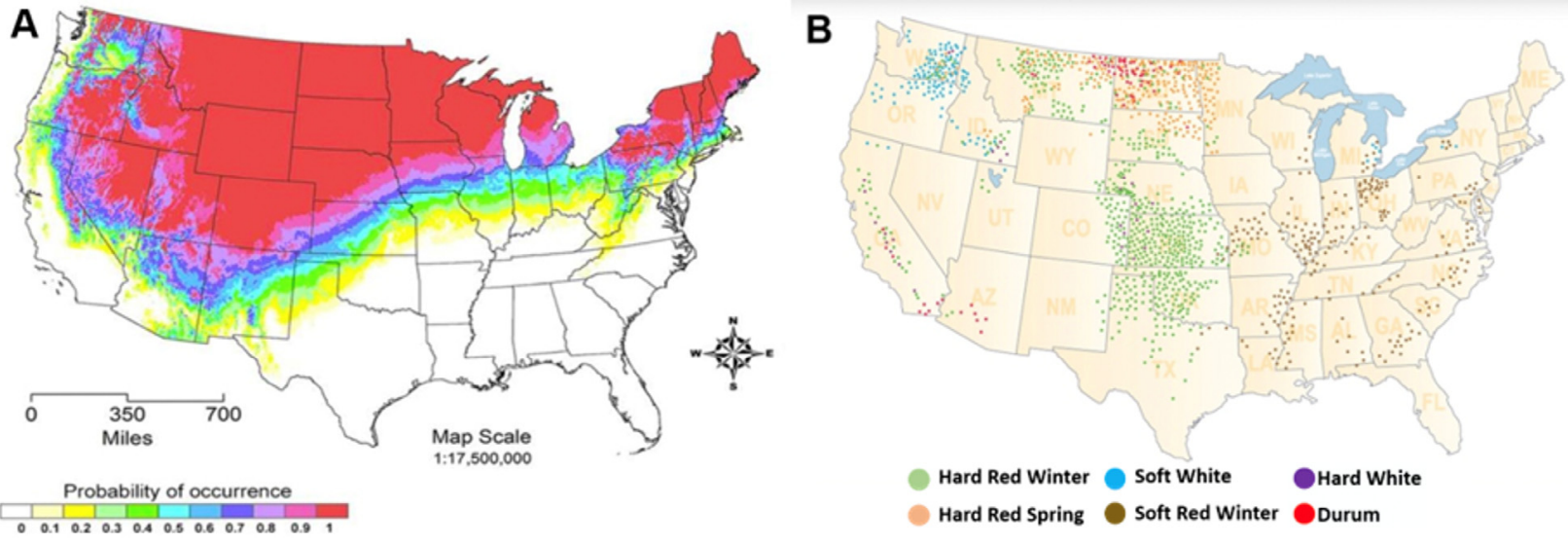

\section{FIGURE 8}

Climate suitability model and U.S. regions growing different wheat classes. A, The model is based on predicted impact of repeated freeze-thaw cycles on inoculum build-up, based on experience with the MoL turf grass disease in the United States and wheat blast in Brazil. Specifically, the model tracks days with freezing temperatures based on weather patterns from 1997 to 2006. Note that the scale is probability of occurrence of freeze-thaw cycles that would limit MoT survival (red zone, $P=1.0$ ) through no freeze-thaw cycles that would limit survival (white zone, $P=0$ ). B, U.S. wheat is divided into six classes based on color, hardness, and growing season, each with qualities necessary for specific wheat end products. With the outdated weather information, all of the soft red winter wheat (SRWW, brown dots, used for cakes and cookies) and over half of the hard red winter wheat (HRWW, green dots, used for breads) are grown in areas where MoT can survive. Soft white wheat (Asian noodles and pastries, blue dots) is grown in a region where MoT could survive. Panel A reproduced from Cruz et al. (2016b); panel B map courtesy of U.S. Wheat Associates (https://www.uswheat.org/working-with-buyers/wheat-classes/). 
for U.S. wheat imports from at-risk countries as well as to develop preparedness plans for early detection and mitigation.

A wheat blast forecasting model for Brazil has proven effective in predicting diseaseconducive weather by taking into account both inoculum potential and favorability for infection (Fernandes et al. 2017). The model was developed using data on hourly weather and wheat blast occurrence in the state of Paraná from 2001 to 2012. This model successfully predicted blast epidemics from subsequent years as well as weather suitability for wheat head blast infection during the spring of 2011 in Kentucky, U.S.A. Finding M. oryzae infections in May in Kentucky was unusual. M. oryzae does not normally appear on susceptible forage and turf grasses and weeds until late July and August, quite often after the winter wheat crop is harvested in mid-June or early July. However, the model retrospectively predicted that, in May 2011, weather in the Princeton area was conducive for early blast inoculum production (Farman et al. 2017; Fernandes et al. 2017). Preliminary forecasting models have been developed for the United States based on weather data and disease reports for rice blast (Fischer 2016) and on experience with forecasting wheat blast in Brazil. It is a priority to deploy accurate prediction models that incorporate crop development stages.

\section{Response}

The USDA APHIS - Plant Protection and Quarantine (PPQ) agency will lead the response to suspected findings of wheat blast in the United States, with cooperation from the National Plant Diagnostic Network (Stack et al. 2014), the USDA-ARS, university scientists and extension specialists, state Departments of Agriculture, and various grower and stakeholder groups on a need-to-know basis. The first step will be identification of the origin of the fungus as either an exotic MoT strain (Figs. 3 and 4) or a native MoL strain (Fig. 9), which will impact downstream responses. However, the

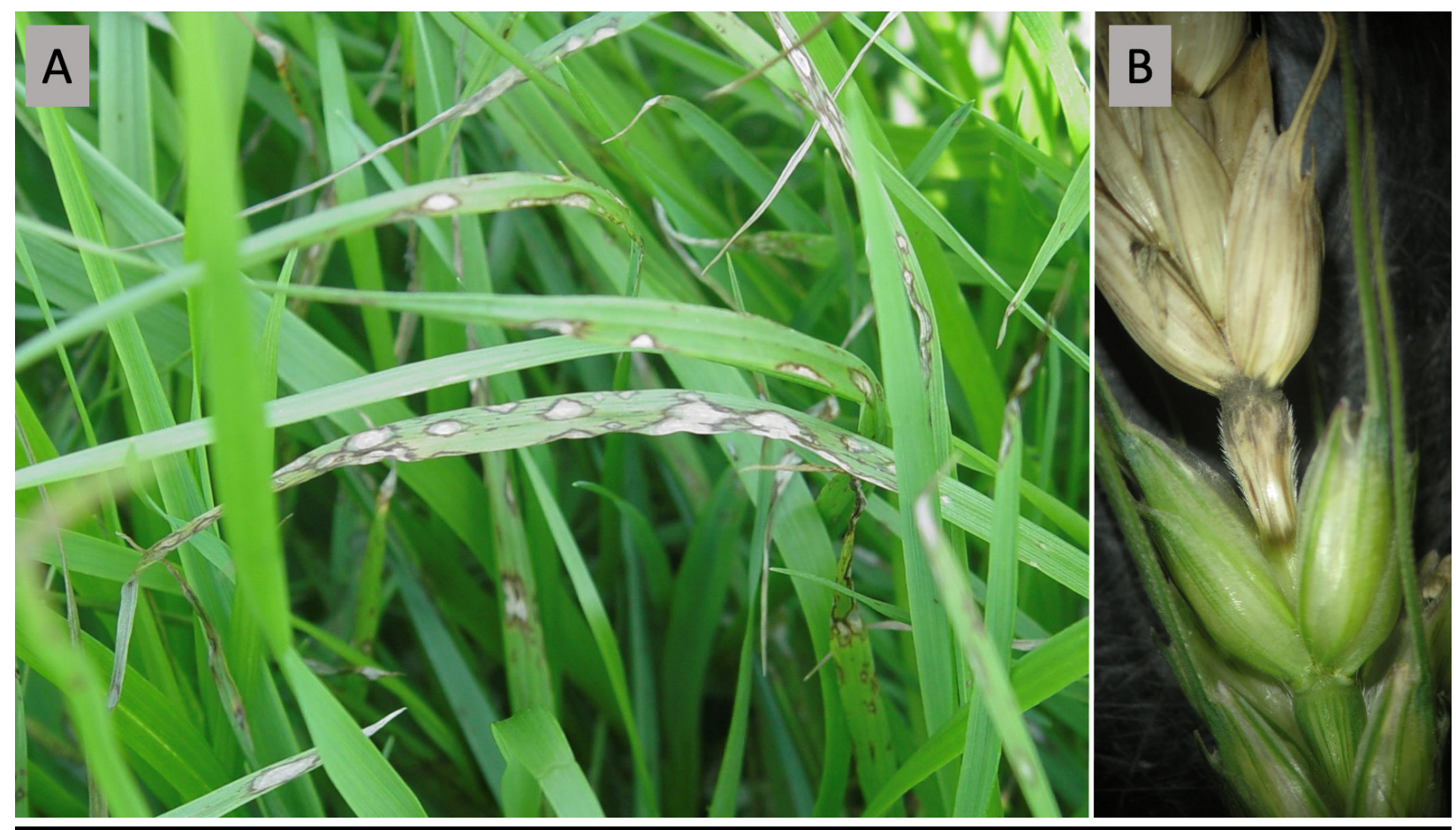

FIGURE 9

Natural infections of tall fescue and wheat by native MoL strains. A, Leaf lesions on tall fescue, also a primary host for MoL. These previously sporulated lesions were found in a home lawn. They resemble lesions on ryegrasses and other relevant alternative hosts. B, Symptoms caused by the MoL strain on the single blasted head in Kentucky in 2011. Photo A by Mark Farman (University of Kentucky); B reproduced from Farman et al. (2017). 
response in both cases should include defining the number of plants or area of $M$. oryzaeinfected wheat, in order to eradicate MoT incursion or to block spread of potential MoL "host jump" strains. This task will most likely be complicated by co-occurrence of FHB (Fig. 4F), which has similar environmental requirements to wheat blast. Therefore, trained surveyors will be required to look closely at bleached heads, including removing spikelets to attempt to visualize the fungus beneath (Figs. 4B, C, and F and 9B). After field validation, the MoT3 LAMP assay will be available to differentiate MoT from both MoL and FHB (Yasuhara-Bell et al. 2018). Wheat farmers near the site of occurrence must adopt preventive measures to avoid wheat blast spread and establishment. Therefore, a farmer-focused preparedness and recovery plan must be in place for general distribution, including surveillance in high-risk areas during blast-conducive years, training of first responders, including state Agriculture Departments, extension specialists, and stakeholders, for proper disease identification. Incorporation of wheat blast into the Cooperative Agricultural Pest Surveys beginning in the 2021 survey season will greatly increase national capacity for identifying wheat blast disease.

Scouting for MoT on alternative hosts. A critical activity for recovery is to identify and eradicate MoT on secondary hosts including weeds surrounding fields and other nearby forage grass hosts. In 2016, blasted wheat fields in Bangladesh were burned in an attempt to eradicate the disease, but this effort failed. The disease recurred and spread to new districts in 2017, despite weather that was not conducive to blast disease. Even if all fungal structures in infected wheat fields could be eliminated, perhaps by plowing instead of burning fields, the MoT strain will certainly have spread to surrounding susceptible grasses. Therefore, more knowledge on alternative MoT hosts is critical, and a strategy for scouting on these hosts must be developed, including scouting for leaf lesions on these hosts (Fig. 9).

\section{Permits and Regulatory Issues}

Due to the threat blast disease poses to U.S. wheat production, exotic MoT isolates must only be housed and experimented on within Biosafety Level-3 (BSL-3) containment facilities approved by the USDA APHIS. Currently, APHIS has issued PPQ526 permits for MoT strain acquisition, storage, and research to two U.S. research groups with BSL-3 facilities. This research occurs in the USDA-ARS Foreign Disease - Weed Science Research Unit (FDWSRU) in Ft. Detrick, MD, and in the Biosecurity Research Institute (BRI) at Kansas State University (KSU) in Manhattan, KS. Strain acquisition, storage, and research with native MoL isolates is less restrictive.

Should a wheat blast outbreak occur in the United States as a result of an introduction of MoT, multiple regulatory issues would arise with respect to mitigation and recovery. For example, currently there are no labeled fungicides for use in forage production (Lemus and Tomaso-Peterson 2018), so controlling MoT that had spread from the outbreak site to forage pastures would require a Section 18 pesticide emergency exemption from the EPA. All such issues should be anticipated and action plans developed before they are needed.

\section{Impact on U.S. Economy and National Security}

Blast is a serious disease of wheat causing yield failures and significant economic losses during epidemic years. Wheat is cultivated on more land than any other commercial crop because of its adaptability to a broad range of environments. Globally, wheat accounts for one-fifth of all calories consumed and is the most important source of food protein worldwide. In the United States, wheat ranks third among field crops in terms of acreage and gross farm receipts (USDA Economic Research Service 2020). The economic importance of wheat blast derives from the fact that the fungus can reduce grain yield and quality (Goulart et al. 2007; Urashima et al. 2009). Infected grains are 
usually small, shriveled, deformed, and have low test weight. Under conducive conditions, yield losses from susceptible varieties range from 10.5 up to $100 \%$. Preliminary climate suitability analyses indicate that all U.S. SRWW and half of U.S. HRWW are at risk for a potential wheat blast establishment (Fig. 8A). SRWW is grown in the eastern third of the United States (Fig. 8B), and it accounts for approximately 15 to $20 \%$ of total wheat production in the country (third largest market wheat class). In the 2019 wheat season, the United States produced $\sim 1.9$ billion bushels of wheat harvested from $\sim 37$ million acres, of which $\sim 239$ million bushels were SRWW ( $12.45 \%$ ) (USDA National Agricultural Statistics Service 2020). SRWW is high yield with low-to-medium protein content, soft endosperm, and weak gluten, which make this class ideal for the production of flour for cakes, cookies, and crackers. Additionally, SRWW is mixed with all-purpose whole wheat flour from HRWW for the production of flatbreads and pastries, among others. HRWW is mainly grown in the Great Plains and California (Fig. $8 \mathrm{~B})$. It is the largest market wheat class in the United States, and it has excellent milling and baking characteristics. This class is used for Asian noodles, pan breads, and general purpose flour, among others. In the 2019 season, the United States planted $\sim 21$ million acres of HRWW with a total production of $\sim 833$ million bushels $(43.4 \%$ of the total wheat production) (USDA National Agricultural Statistics Service 2020).

In addition to the impact on the U.S. economy, wheat blast can impact U.S. national security. The spread and establishment of the disease in Bangladesh in 2016 increased its potential for further spread to other regions in South Asia, such as India and Pakistan. India is the second largest wheat producer, and Pakistan ranked seventh in 2018. Wheat is the second most important crop in both Bangladesh and India, only after rice, but it ranks first in Pakistan. Resource-poor, smallholder farmers are responsible for a significant portion of the wheat produced in these countries, which increases the potential for socioeconomic and public health impacts in an already precarious, high-tension, poor, and densely populated region. A conservative impact assessment based on agroclimatic conditions estimated that $\sim 65 \%$ of wheat cultivated area in Bangladesh is vulnerable to wheat blast, whereas $\sim 21 \%$ of the wheat area in India is vulnerable, representing 6.57 million hectares distributed in 138 districts in 11 states (Mottaleb et al. 2018). According to this analysis, the scenario is better in Pakistan, where only $\sim 1.5 \%$ of the wheat area is vulnerable to wheat blast. This conservative risk assessment only holds if MoT does not follow the example of rice blast in adapting to temperate climates in the northern regions of India and Pakistan, where rice blast is currently a serious problem (Khush and Jena 2009; Valent et al. 2020). In any case, potential economic losses in the region due to wheat blast would further threaten the already vulnerable local food security, affecting wheat prices and imports, which can ultimately escalate to a worldwide food shortage and a political security matter.

\section{Mitigation and Disease Control}

Integrated disease management is recommended if the disease is introduced or where it is already established. This strategy should include cultural controls, including adjusting the planting date to avoid heading under warm and rainy conditions, as is currently practiced in all blast-endemic regions (Coelho et al. 2016). Removal of infected crop residue or alternative hosts and use of healthy, certified wheat seeds should eliminate inoculum sources. As with rice blast, both wheat and ryegrass diseases are favored by high nitrogen fertilization (Silva et al. 2019; Williams et al. 2001). Indeed, reported factors contributing to the 1971 blast epidemic on ryegrass and wheat forage grasses in Louisiana and Mississippi were early planting by some farmers; unseasonably warm, humid weather through November; and higher than usual rates of application of nitrogen fertilizers: all factors generally known to favor blast diseases (Rush and Carver 1973). Mineral nutrition of the wheat crop matters; plants supplied with high silicon and low magnesium are more resistant to wheat blast (Rodrigues et al. 
2017). The above strategies must be combined with use of fungicide seed treatments and with the application of fungicides when the weather is conducive (Cruz et al. 2019; Rodrigues et al. 2017). Rotation of fungicide active ingredients is recommended given the recent reports of fungicide resistance in Brazil (Castroagudín et al. 2015). And importantly, the wheat varieties planted should have at least moderate levels of blast resistance. Although it is unlikely that all these strategies will be implemented every season, wheat producers should consider their unique cropping systems and use as many control strategies as possible to minimize disease development and consequent losses. The specifics of each strategy will have to be adapted depending on location and year.

Fungicide seed treatment and foliar fungicides. Chemical treatments have been extensively used to mitigate losses due to rice blast; however, their efficacy and profitability for controlling wheat blast are still uncertain. Because MoT-infected seeds can be asymptomatic (Kiyuna 2019), the use of fungicide seed treatment is highly recommended in blast-affected areas. Although the control window is usually only 2 to 3 weeks, fungicide seed treatment can reduce the initial inoculum and reduce spread of the fungus. The effect of fungicide seed treatment in affecting the disease at the head stage has not been demonstrated. Research from Bolivia has indicated that inoculum from the basal leaves early in the season can contribute to infection at the head stage in a susceptible host population (Cruppe 2019), and under these circumstances, seed treatment could be critical to minimize the initial inoculum. Despite lack of recent research reports with seed treatments for wheat blast, the combination of carbendazim and thiram at a rate of $200 \mathrm{ml} / 100 \mathrm{~kg}$ of seeds has been suggested to be effective in Bolivia. Because private and public breeders conduct winter increases of valuable U.S. wheat germplasm in South America, an effective fungicide seed treatment is critical. A useful resource for potential fungicide seed treatment is http://msuextension.org/publications/ AgandNaturalResources/MT199608AG.pdf.

There is no official recommendation regarding fungicide management in Bolivia and Brazil due to the inconsistency in benefits. In blast-affected areas, wheat producers depend on multiple applications of foliar fungicide at different heading stages when the weather is blast conducive. In a recent report combining 23 site-years of data, quinone outside inhibitor (QoI) and sterol demethylation inhibitor (DMI) fungicides were more effective in Bolivia under moderate to high disease pressure than they were in Brazil (Cruz et al. 2019). In Brazil, mancozeb-based fungicides performed better, but not always at levels to be cost effective. The contrasting results in these countries may suggest fungicide resistance with specific fungal populations, which is in agreement with previous reports showing reduced efficacy for QoI and DMI fungicides in Brazil. This adds an additional challenge to control the disease (Castroagudín et al. 2015; Goulart and Paiva 1993).

Two preventive fungicide applications have been unofficially recommended by the Bolivian growers' association Asociación de Productores de Oleaginosas y Trigo (ANAPO) when the weather conditions are conducive for blast development (ANAPO 2015). The first application should occur with approximately 30 to $50 \%$ head emergence, and the second application should occur about 5 to 7 days after the first application, when $100 \%$ of heads are fully emerged. Strobilurins (QoI) plus triazoles (DMI) and benzothiazole-based fungicides should be used. Most of the fungicides showing satisfactory levels of wheat blast control both in Brazil and in Bolivia are labeled for use in wheat in the United States targeting other fungal diseases, although rate and timing of application would have to be adjusted specifically for wheat blast. Together with the fungicide management in Bolivia, ANAPO has recommended not planting prior to April 20 (i.e., to avoid wheat heading under warm and rainy conditions); the use of moderately resistant varieties; crop rotation with nonhosts of M. oryzae; the use of healthy and certified seeds; tillage; controlling seed planting density; and appropriate fertilizer management (ANAPO 2015). Given the recent reports of leaf blast occurrence during blast epidemic years, research trials are being conducted in Bolivia with the 
objective to evaluate the efficacy of fungicide applications during the tillering and flag leaf stages to reduce blast infection at the head stage.

Resistance. The identification and deployment of durable and broad-spectrum resistance are urgently needed to mitigate losses due to this devastating and evolving pathogen. Since 2010, thousands of U.S. elite wheat varieties and breeding lines, international varieties and breeding lines, landraces, and wheat wild relatives (Aegilops tauschii and Aegilops uniaristata) have been evaluated for blast resistance using a diverse set of MoT isolates with different degrees of aggressiveness (Bockus et al. 2012; Cruppe 2019; Cruz et al. 2012, 2016c). All MoT experiments in the United States are performed in BSL-3 laboratories at KSU and the USDA-ARS FDWSRU in Ft. Detrick. Comparison of results from two BSL-3 laboratories using different plant growth conditions confirms putative resistances. Resistance is further validated under field conditions with additional isolates at a Wheat Blast Screening Nursery established in Bolivia in 2010 (see Infrastructure and Experts). The majority of the tested wheat varieties are susceptible. Observation that several varieties with head blast resistance shared a common trait, the $2 \mathrm{~N}^{\mathrm{v}} \mathrm{S}$ translocation, was followed by use of $2 \mathrm{~N}^{\mathrm{v}} \mathrm{S}$ molecular markers to expand the correlation. Finally, $2 \mathrm{~N}^{\mathrm{v}} \mathrm{S}$-based resistance to head blast was demonstrated by direct comparison of isogenic lines with and without the $2 \mathrm{~N}^{v} \mathrm{~S}$ translocation under assay conditions in three locations in Bolivia (Cruz et al. 2016c). This translocation was introgressed from the wheat wild relative Aegilops ventricosa, and it had already been widely deployed in wheat breeding programs in the United States and worldwide because it also contains several rust and nematode resistance genes. Although not complete, the majority of the $2 \mathrm{~N}^{v} \mathrm{~S}$-based varieties have some level of wheat blast resistance to most MoT strains assayed so far, and their use is highly recommended where the disease is present and in surrounding areas. However, its effectiveness appears to have been overcome by a newly emerged, highly aggressive strain isolated in Brazil in 2016 (Cruppe et al. 2020).

The major goal now is to identify additional resistance genes to pyramid with the $2 \mathrm{~N}^{v} \mathrm{~S}$ resistance. Genome-wide association study (GWAS) is a powerful strategy used in several crops to identify $R$ genes associated with a trait of interest. To date, three GWASs have been performed exploring wheat blast resistance (Cruppe 2019; Cruppe et al. 2021; Juliana et al. 2019, 2020). In these studies, the major effect was identified on chromosome $2 \mathrm{~A}$, which was associated with the $2 \mathrm{~N}^{v} \mathrm{~S}$ translocation. Other genomic regions with minor effects were also detected; however, their combination was not significantly different from the individual effect of the $2 \mathrm{~N}^{v} \mathrm{~S}$. These regions still might contribute toward durable and broader resistance, but more research is needed to test this hypothesis. In separate studies, a few non- $2 \mathrm{~N}^{\mathrm{v}} \mathrm{S}$-based breeding lines and wild relatives were classified as moderately resistant ( $>5 \%$ and $<25 \%$ disease severity) to head blast using aggressive MoT strains; however, the source of resistance present in these genotypes is still unknown (Cruppe et al. 2020). The development of biparental populations and mapping analyses are needed to unravel the basis of the resistance. If promising results are obtained, these novel resistance sources should be introgressed into $2 \mathrm{~N}^{\mathrm{v}} \mathrm{S}$-based genotypes.

In addition to the $2 \mathrm{~N}^{\mathrm{v}} \mathrm{S}$, five $R$ genes (Rmg2, $R m g 3, R m g 7, R m g 8$, and $R m g G R 119$ ) were previously reported as effective against MoT strains isolated in the early 1990s (Wang et al. 2018). However, genes Rmg2, Rmg3, Rmg7, and Rmg8 were no longer effective when tested under temperatures higher than $26^{\circ} \mathrm{C}$, when using recently collected aggressive strains, or at the critical head stage. The combination of Rmg8 and RmgGR119 genes showed an additive effect compared with Rmg8 alone, but the level of control was still not ideal in Bolivia. When the susceptible checks reached disease severity of $90 \%$ or more, Rmg 8 averaged $95.1 \%$ and the combination of the two genes averaged $73.1 \%$ using the aggressive Bolivian MoT isolate 008. Follow-up experiments will be conducted using additional MoT isolates. 
Given the sparsity of resistance genes in wheat, the strategy of using rice $R$ genes has been evaluated in wheat using conventional transgenic methods. Homologs for $\mathrm{MoO} A V R$ genes corresponding to characterized rice $R$ genes are present in the MoT genome (Peng et al. 2019). The MoT homologs can be tested for AVR function by transforming them into $\mathrm{MoO}$ strains to show they trigger the corresponding $R$ genemediated resistance in rice. Because MoT strain T-25 contains a functional AVR homo$\log$ of the MoO effector AVR-Piz-t (M. Farman, University of Kentucky, personal communication), the effect of the rice $R$ gene Piz-t was evaluated to control both leaf and head blast in wheat using strain T-25 (Navia-Urrutia 2020). Although two transformed wheat lines had significant reduction in the percentage of leaf area affected, no enhancement of head blast $R$ was observed for any of the lines. Still, these results are important considering the increase of reports of leaf symptoms in commercial fields during blast epidemic years. Additionally, despite the low correlation between leaf and head blast resistance for some specific varieties, recent field experiments suggest that inoculum from basal leaves early in the season can contribute to head infection (Cruppe 2019). Therefore, $R$ genes effective in the leaf stage should be introgressed in varieties with head blast resistance. CRISPR/Cas9 technology also holds promise for future control of wheat blast, although early experiments demonstrate the need for more research on good targets for wheat blast control.

\section{Research, Extension, and Education Priorities}

\section{RESEARCH NEEDS}

\section{Monitoring and Detection}

- Validate the MoT3 LAMP assay in the field and continue monitoring of the MoT populations in South America, South Asia, and Africa.

- Develop next-generation diagnostic protocols based on new genomic understanding of $M$. oryzae pathotype/lineage structure and recombination events, past and present.

- Develop more sensitive sampling protocols for testing seed lots for MoTinfested/infected seeds, and develop global seed health strategies to minimize movement of MoT-infected seed.

- Continue developing, evaluating, and refining disease forecasting and risk assessment models for both leaf and head blast in order to guide monitoring efforts.

- Study impact of global warming on wheat blast risk.

\section{Chemical Control and Disease Management}

- Continue monitoring the emergence and spread of fungicide resistance in MoT field populations.

- Design a chemistry rotation and deployment strategy to minimize the development of MoT populations with multi-fungicide resistance and extend the useful life of fungicide chemistries.

- Evaluate effects of fungicide application technology such as nozzle type and orientation on fungicide efficacy against leaf and head blast.

- Document the procedure for obtaining an Environmental Protection Agency - FIFRA Section 18 Pesticide Emergency Exemption for emergency unregistered use of fungicides.

\section{Resistance}

- Develop high-throughput phenotyping techniques for wheat blast quantification under controlled and field conditions.

- Identify new resistance sources and develop molecular markers to incorporate these resistances into U.S. wheat varieties. 
- Continue screening wheat wild relatives to identify effective blast resistance genes.

- Develop a set of spring wheat differentials for the characterization of race structure.

- Understand potential for race structure in the wheat pathogen population and the potential for resistance genes to be defeated by evolution of new races.

- Continue to explore transgenic and genome-editing strategies for producing blast-resistant wheat for that time when these strategies are approved for use in farmers' fields.

\section{Epidemiology}

- Determine if leaf blast symptoms are increasing in the field as reported, and if so, why.

- Determine the efficacy of foliar fungicide applications at tillering and flag leaf stages on temporal and spatial dynamics of head blast.

- Determine the rate of MoT transmission from infected seeds to seedlings and to heads using host genotypes with different types (e.g., seedling versus head) and levels of resistance.

- Quantify the relationship between blast intensity and grain yield to ascertain damage threshold as influenced by cultivar resistance and growing conditions.

- Determine MoT survival under field conditions, particularly in response to freeze-thaw cycles.

- Determine if sexual reproduction is still occurring in MoT populations in the field and how this impacts disease development and control strategies.

- Collect disease progress, host development, and microclimate data during outbreak and non-outbreak years to determine the rate of epidemic development and the relationship between the disease development on leaves and heads.

- Continue studies to better understand relationships between leaf and head blasts and among different measures of head blast intensity.

- Continue studying the spatio-temporal development of wheat blast under commercial field conditions, and factors affecting the same.

- Continue evaluating the strength and importance of in-field and external sources of inoculum for wheat blast development.

- Determine mechanisms of seed transmission of MoT.

\section{Host Specificity and Evolutionary Potential of the MoT Fungus}

- Identify alternative MoT hosts that could serve as reservoirs and inoculum sources.

- Determine the genetic structures of the highly diverse MoT population in South America and of the newly established bottle-neck populations derived from a single founding strain introduced into South Asia and Africa.

- Determine the current potential for sexual and/or parasexual recombination between MoT strains and strains of other host-adapted pathotypes to impact host specificity.

- Identify MoT effectors including AVR effectors determining host specificity.

- Understand how effector gene locations in unstable genome regions, at chromosome ends and on dispensable supernumerary mini-chromosomes, contribute to the rapid ability of the fungus to mutate and overcome $R$ gene-mediated resistance.

- Understand the potential for MoT to evolve to resemble the current MoO pathotype in causing severe disease in temperate climates, thus expanding the at-risk wheat area. 
- Understand the potential for MoT strains in South Asia to recombine with sexually fertile rice pathogens that occur in the nearby Himalayan foothills and give rise to aggressive pathogens of both rice and wheat to further threaten the rice-wheat cropping systems in India and China.

\section{Risk from Native MoL Strains}

- Continue evaluating the biology and epidemiology of MoL-incited wheat blast.

- Monitor MoL blast in primary hosts annual and perennial ryegrasses and tall fescue in U.S. wheat-growing regions.

- Continue understanding the population structure of native MoL strains and ability to infect wheat and alternative grass hosts.

\section{EXTENSION AND EDUCATION NEEDS}

Wheat blast has already been incorporated into some extension publications, and training workshops have been developed for wheat stakeholders including farmers, plant disease diagnosticians, extension and research specialists (agronomists, plant pathologists) and other agricultural professionals, national, regional and state commodity leaders, and decision makers. Inclusion of wheat blast in the APHIS CAPS survey program makes the production of training materials that differentiate wheat head blast symptoms from FHB a high priority. Future extension materials and training workshops should focus on wheat blast forecasting models and on training extension specialists, crop consultants, farm advisors/educators, and growers to use prediction models to evaluate the risk of blast epidemics and modify management strategies. Outreach efforts should be dovetailed with NCERA184 and WERA97 to avoid duplication of effort and promote inter-group cooperation and activities. Education activities should focus on training new generations of scientists in the critical area of plant biosecurity and on educating the general public on the importance of research, extension, and education for issues relating to global food security.

\section{ACIKNOWLEDGMENTS}

Wheat blast research has been supported by past and ongoing projects at the USDAARS Foreign Disease-Weed Science Research Unit in Ft. Detrick, MD, including USDA Agricultural Research Service projects 8044-22000-046-00D and 8044-22000-04606-R, in addition to United States Agency for International Development (USAID) Agreement 021-022310-004-96-R. Past and ongoing wheat blast research has also been funded by competitive grants from the USDA National Institute of Food and Agriculture under awards \#2009-55605-05201 (2009 to 2012), \#2013-68004-20378 (2013 to 2019), and \#2021-68013-33719 (2021 to 2024). The NIFA project beginning in 2013, known as the Blast Integrated Project, included research and extension specialists from diverse universities and institutions in the United States and South America. We acknowledge support from the National Plant Disease Recovery System (NPDRS) of the USDA-Office of Pest Management Policy through Dr. Timothy L. Widmer (National Program Leader-Plant Health, USDA/ARS, Beltsville, MD). This is contribution 21-120-J from the Agricultural Experiment Station at Kansas State University.

\section{References}

Alves, K. J. P., and Fernandes, J. M. C. 2006. Influence of temperature and relative air humidity on the sporulation of Magnaporthe grisea on wheat. Fitopatol. Bras. 31:579584.

ANAPO. 2015. Recomendaciones Técnicas para el cultivo de trigo. Asociación de Productores de Oleaginosas y Trigo, Santa Cruz, Bolivia.

Bain, D., Patel, B., and Patel, M. 1972. Blast of ryegrass in Mississippi. Plant Dis. Rep. $56: 210$.

Bienapfl, J. C., Jennings, K. C., Pedley, K. F., Stack, J. P., and Abad, Z. G. 2018. Validation of molecular diagnostic methods for specific detection of Magnaporthe oryzae Triticum 
pathotype, the causal agent of wheat blast. (Abstr.). Phytopathology 108:S101.165. https://doi.org/10.1094/PHYTO-108-10-S1.1.

Bockus, W., Cruz, C., Kalia, B., Gill, B., Stack, J., Pedley, K., Peterson, G., and Valent, B. 2012. Reaction of selected accessions of Aegilops tauschii to wheat blast, 2011. Plant Dis. Manage. Rep. 6:CF005.

Cardoso, C. A. d. A., Reis, E. M., and Moreira, E. N. 2008. Development of a warning system for wheat blast caused by Pyricularia grisea. Summa Phytopathol. 34:216-221.

Carver, R., Rush, M., and Lindberg, D. 1972. An epiphytotic of ryegrass blast in Louisiana. Plant Dis. Rep. 56:157-159.

Castroagudín, V. L., Ceresini, P. C., de Oliveira, S. C., Reges, J. T. A., Maciel, J. L. N., Bonato, A. L. V., Dorigan, A. F., and McDonald, B. A. 2015. Resistance to QoI fungicides is widespread in Brazilian populations of the wheat blast pathogen Magnaporthe oryzae. Phytopathology 105:284-294.

Ceresini, P. C., Castroagudín, V. L., Rodrigues, F. Á., Rios, J. A., Aucique-Pérez, C. E., Moreira, S. I., Alves, E., Croll, D., and Maciel, J. L. N. 2018. Wheat blast: Past, present, and future. Annu. Rev. Phytopathol. 56:427-456.

Chuma, I., Shinogi, T., Hosogi, N., Ikeda, K.-i., Nakayashiki, H., Park, P., and Tosa, Y. 2009. Cytological characteristics of microconidia of Magnaporthe oryzae. J. Gen. Plant Pathol. 75:353-358.

Chuma, I., Isobe, C., Hotta, Y., Ibaragi, K., Futamata, N., Kusaba, M., Yoshida, K., Terauchi, R., Fujita, Y., Nakayashiki, H., Valent, B., and Tosa, Y. 2011. Multiple translocation of the AVR-Pita effector gene among chromosomes of the rice blast fungus Magnaporthe oryzae and related species. PLoS Pathog. 7:e1002147.

Coelho, M. A. d. O., Torres, G. A. M., Cecon, P. R., and Santana, F. M. 2016. Sowing date reduces the incidence of wheat blast disease. Pesqui. Agropecu. Bras. 51:631-637.

Couch, B. C., Fudal, I., Lebrun, M.-H., Tharreau, D., Valent, B., van Kim, P., Notteghem, J.-L., and Kohn, L. M. 2005. Origins of host-specific populations of the blast pathogen Magnaporthe oryzae in crop domestication with subsequent expansion of pandemic clones on rice and weeds of rice. Genetics 170:613-630.

Cruppe, G. 2019. Identifying new sources associated with wheat blast resistance, understanding the background effect of 2NS-based resistance, and characterizing the basic ecology of Magnaporthe oryzae Triticum. Ph.D. thesis. Kansas State University, Manhattan, KS.

Cruppe, G., Cruz, C. D., Peterson, G., Pedley, K., Asif, M., Fritz, A., Calderon, L., Lemes da Silva, C., Todd, T., Kuhnem, P., Singh, P. K., Singh, R. P., Braun, H.-J., Barma, N. C. D., and Valent, B. 2020. Novel sources of wheat head blast resistance in modern breeding lines and wheat wild relatives. Plant Dis. 104:35-43.

Cruppe, G., Silva, P., da Silva, C. L., Peterson, G., Pedley, K. F., Cruz, C. D., Asif, M., Lollato, R. P., Fritz, A. K., and Valent, B. 2021. Genome wide association reveals limited benefits of pyramiding the 1B and 1D loci with the 2NS translocation for wheat blast control. Crop Sci. 61:1089-1103.

Cruz, C. D. 2013. Wheat blast: Quantitative pathway analyses for the Triticum pathotype of Magnaporthe oryzae and phenotypic reaction of U.S. wheat cultivars. Ph.D. thesis. Kansas State University, Manhattan, KS.

Cruz, C. D., and Valent, B. 2017. Wheat blast disease: Danger on the move. Trop. Plant Pathol. 42:210-222.

Cruz, C. D., Kiyuna, J., Bockus, W. W., Todd, T. C., Stack, J. P., and Valent, B. 2015. Magnaporthe oryzae conidia on basal wheat leaves as a potential source of wheat blast inoculum. Plant Pathol. 64:1491-1498.

Cruz, C. D., Bockus, W. W., Stack, J. P., Tang, X., Valent, B., Pedley, K. F., and Peterson, G. L. 2012. Preliminary assessment of resistance among U.S. wheat cultivars to the Triticum pathotype of Magnaporthe oryzae. Plant Dis. 96:1501-1505.

Cruz, C. D., Bockus, W. W., Stack, J. P., Valent, B., Maciel, J. N., and Peterson, G. L. $2016 \mathrm{a}$. A standardized inoculation protocol to test wheat cultivars for reaction to head blast caused by Magnaporthe oryzae (Triticum pathotype). Plant Health Progr. 17:186-187.

Cruz, C. D., Magarey, R. D., Christie, D. N., Fowler, G. A., Fernandes, J. M., Bockus, W. W., Valent, B., and Stack, J. P. 2016b. Climate suitability for Magnaporthe oryzae Triticum pathotype in the United States. Plant Dis. 100:1979-1987.

Cruz, C. D., Peterson, G. L., Bockus, W. W., Kankanala, P., Dubcovsky, J., Jordan, K. W., Akhunov, E., Chumley, F., Baldelomar, F. D., and Valent, B. 2016c. The 2NS translocation from Aegilops ventricosa confers resistance to the Triticum pathotype of Magnaporthe oryzae. Crop Sci. 56:990-1000.

Cruz, C. D., Santana, F. M., Todd, T. C., Maciel, J. L. N., Kiyuna, J., Baldelomar, D. F., Cruz, A. P., Lau, D., Seixas, C. S., Goulart, A. C. P., Sussel, A. A., Schipanski, C. A., Chagas, D. F., Coelho, M., Montecelli, T. D. N., Utiamada, C., Custódio, A. P., Rivadeneira, M. G., Bockus, W. W., and Valent, B. 2019. Multi-environment assessment 
of fungicide performance for managing wheat head blast (WHB) in Brazil and Bolivia. Trop. Plant Pathol. 44:183-191.

De Wolf, E. D. 2019. Fusarium Head Blight. MF3458. KSU Research and Extension, Department of Plant Pathology, Kansas State University, Manhattan, KS.

Duveiller, E., He, X., and Singh, P. K. 2016. Wheat blast: An emerging disease in South America potentially threatening wheat production. Pages 1107-1122 in: The World Wheat Book, Volume 3 : A History of Wheat Breeding. A. P. Bonjean, W. J. Angus, and M. van Ginkel, eds. Lavoisier, Paris, France.

Faivre-Rampant, O., Geniès, L., Piffanelli, P., and Tharreau, D. 2013. Transmission of rice blast from seeds to adult plants in a non-systemic way. Plant Pathol. 62:879-887.

Farman, M., Peterson, G. L., Chen, L., Starnes, J. H., Valent, B., Bachi, P., Murdock, L., Hershman, D. E., Pedley, K. F., Fernandes, J. M. C., and Bavaresco, J. 2017. The Lolium pathotype of Magnaporthe oryzae recovered from a single blasted wheat plant in the United States. Plant Dis. 101:684-692.

Fernandes, J. M. C., Nicolau, M., Pavan, W., Hölbig, C. A., Karrei, M., de Vargas, F., Bavaresco, J. L. B., Lazzaretti, A. T., and Tsukahara, R. Y. 2017. A weather-based model for predicting early season inoculum build-up and spike infection by the wheat blast pathogen. Trop. Plant Pathol. 42:230-237.

Fernandez-Campos, M., Gongora-Canul, C., Das, S., Kabir, M. R., Valent, B., and Cruz, C. D. 2020. Epidemiological criteria to support breeding tactics against the emerging, high-consequence wheat blast disease. Plant Dis. 104:2252-2261.

Fischer, T. D. 2016. Influence of freezing on the survival of Magnaporthe oryzae and weather conditions that favor blast epidemics in rice. M.S. thesis. Kansas State University, Manhattan, KS.

Gladieux, P., Condon, B., Ravel, S., Soanes, D., Maciel, J. L. N., Nhani, A., Chen, L., Terauchi, R., Lebrun, M.-H., Tharreau, D., Mitchell, T., Pedley, K. F., Valent, B., Talbot, N. J., Farman, M., and Fournier, E. 2018. Gene flow between divergent cereal- and grass-specific lineages of the rice blast fungus Magnaporthe oryzae. mBio 9:e0121901217.

Gomes, D. P., Rocha, V. S., Rocha, J. R. A. S. d. C., Souza, M. A. d., and Pereira, O. L. 2019. Progresso temporal da brusone do trigo em função do inóculo primário, da aplicação de fungicida e da resistência dos genótipos. Summa Phytopathol. 45:50-58.

Gongora-Canul, C., Salgado, J. D., Singh, D., Cruz, A. P., Cotrozzi, L., Couture, J., Rivadeneira, M. G., Cruppe, G., Valent, B., Todd, T., Poland, J., and Cruz, C. D. 2020. Temporal dynamics of wheat blast epidemics and disease measurements using multispectral imagery. Phytopathology 110:393-405.

Goulart, A. C. P., and Paiva, F. A. 1993. Evaluation of fungicides in the control of wheat (Triticum aestivum) blast (Pyricularia oryzae). Fitopatol. Bras. 18:167-173.

Goulart, A. C. P., Sousa, P. G., and Urashima, A. S. 2007. Damages in wheat caused by infection of Pyricularia grisea. Summa Phytopathol. 33:358-363.

Gupta, D. R., Avila, C. S. R., Win, J., Soanes, D. M., Ryder, L. S., Croll, D., Bhattacharjee, P., Hossain, M. S., Mahmud, N. U., Mehebub, M. S., Surovy, M. Z., Rahman, M. M., Talbot, N. J., Kamoun, S., and Islam, M. T. 2019. Cautionary notes on use of the MoT3 diagnostic assay for Magnaporthe oryzae wheat and rice blast isolates. Phytopathology 109:504-508.

Harmon, P. F., and Latin, R. 2005. Winter survival of the perennial ryegrass pathogen Magnaporthe oryzae in North Central Indiana. Plant Dis. 89:412-418.

Heath, M. C., Valent, B., Howard, R. J., and Chumley, F. G. 1990. Interactions of two strains of Magnaporthe grisea with rice, goosegrass, and weeping lovegrass. Can. J. Bot. 68: 1627-1637.

Howard, R. J., and Valent, B. 1996. Breaking and entering: Host penetration by the fungal rice blast pathogen Magnaporthe grisea. Annu. Rev. Microbiol. 50:491-512.

Igarashi, S. 1990. Update on wheat blast (Pyricularia oryzae) in Brazil. Pages 480-483 in: Wheat for the Nontraditional Warm Areas: A Proceedings of the International Conference, Foz Do Iguaçu, Brazil. D. A. Saunders, ed.

Inoue, Y., Vy, T. T. P., Yoshida, K., Asano, H., Mitsuoka, C., Asuke, S., Anh, V. L., Cumagun, C. J. R., Chuma, I., Terauchi, R., Kato, K., Mitchell, T., Valent, B., Farman, M., and Tosa, Y. 2017. Evolution of the wheat blast fungus through functional losses in a host specificity determinant. Science 357:80-83.

Islam, M. T., Croll, D., Gladieux, P., Soanes, D. M., Persoons, A., Bhattacharjee, P., Hossain, M. S., Gupta, D. R., Rahman, M. M., Mahboob, M. G., Cook, N., Salam, M. U., Surovy, M. Z., Sancho, V. B., Maciel, J. L. N., Nhani, A., Castroagudin, V. L., Reges, J. T. D., Ceresini, P. C., Ravel, S., Kellner, R., Fournier, E., Tharreau, D., Lebrun, M. H., McDonald, B. A., Stitt, T., Swan, D., Talbot, N. J., Saunders, D. G. O., Win, J., and Kamoun, S. 2016. Emergence of wheat blast in Bangladesh was caused by a South American lineage of Magnaporthe oryzae. BMC Biol. 14:84. 
Juliana, P., He, X., Kabir, M. R., Roy, K. K., Anwar, M. B., Marza, F., Poland, J., Shrestha, S., Singh, R. P., and Singh, P. K. 2020. Genome-wide association mapping for wheat blast resistance in CIMMYT's international screening nurseries evaluated in Bolivia and Bangladesh. Sci. Rep. 10:15972.

Juliana, P., Poland, J., Huerta-Espino, J., Shrestha, S., Crossa, J., Crespo-Herrera, L., Toledo, F. H., Govindan, V., Mondal, S., Kumar, U., Bhavani, S., Singh, P. K., Randhawa, M. S., He, X., Guzman, C., Dreisigacker, S., Rouse, M. N., Jin, Y., PérezRodríguez, P., Montesinos-López, O. A., Singh, D., Mokhlesur Rahman, M., Marza, F., and Singh, R. P. 2019. Improving grain yield, stress resilience and quality of bread wheat using large-scale genomics. Nature Genet. 51:1530-1539.

Kato, H. 1974. Epidemiology of rice blast disease. Rev. Plant Prot. Res. 7:1-20.

Kato, H., Mayama, S., Sekine, R., Kanazawa, E., Izutani, Y., Urashima, A. S., and Kunoh, H. 1994. Microconidium formation in Magnaporthe grisea. Ann. Phytopathol. Soc. Jpn. 60:175-185.

Kato, H., Yamamoto, M., Yamaguchi-Ozaki, T., Kadouchi, H., Iwamoto, Y., Nakayashiki, H., Tosa, Y., Mayama, S., and Mori, N. 2000. Pathogenicity, mating ability and DNA restriction fragment length polymorphisms of Pyricularia populations isolated from Gramineae, Bambusideae and Zingiberaceae plants. J. Gen. Plant Pathol. 66:30-47.

Khush, G. S., and Jena, K. K. 2009. Current status and future prospects for research on blast resistance in rice (Oryza sativa L.). Pages 1-10 in: Advances in Genetics, Genomics and Control of Rice Blast Disease. G. L. Wang and B. Valent, eds. Springer, Dordrecht, The Netherlands.

Kiyuna, J. 2019. Detection of wheat blast within and on wheat seeds and preliminary risk evaluation tool for the detection of MoT infected seeds. M.S. thesis. Kansas State University, Manhattan, KS.

Kohli, M. M., Mehta, Y. R., Guzman, E., Viedma, L., and Cubilla, L. E. 2011. Pyricularia blast-A threat to wheat cultivation. Czech J. Genet. Plant Breed. 47:S130-S134.

Landschoot, P. J., and Hoyland, B. F. 1992. Gray leaf-spot of perennial ryegrass turf in Pennsylvania. Plant Dis. 76:1280-1282.

Lemus, R., and Tomaso-Peterson, M. 2018. Gray leaf spot (blast) in annual ryegrass. Mississppi State University Extension Publication number 2633. http://extension.msstate.edu/ publications/publications/gray-leaf-spot-blast-annual-ryegrass. Accessed January 31, 2021.

Maciel, J. L. N. 2011. Magnaporthe oryzae, the blast pathogen: Current status and options for its control. CAB Rev. 6:1-8.

Maciel, J. L. N., Ceresini, P. C., Castroagudin, V. L., Zala, M., Kema, G. H. J., and McDonald, B. A. 2014. Population structure and pathotype diversity of the wheat blast pathogen Magnaporthe oryzae 25 years after its emergence in Brazil. Phytopathology 104:95-107.

Malaker, P. K., Barma, N. C. D., Tiwari, T. P., Collis, W. J., Duveiller, E., Singh, P. K., Joshi, A. K., Singh, R. P., Braun, H. J., Peterson, G. L., Pedley, K. F., Farman, M. L., and Valent, B. 2016. First report of wheat blast caused by Magnaporthe oryzae pathotype triticum in Bangladesh. Plant Dis. 100:2330.

Manyasa, E. O., Tongoona, P., Shanahan, P., Githiri, S., Ojulong, H., and Njoroge, S. M. C. 2019. Exploiting genetic diversity for blast disease resistance sources in finger millet (Eleusine coracana). Plant Health Progr. 20:180-186.

Marcel, S., Sawers, R., Oakeley, E., Angliker, H., and Paszkowski, U. 2010. Tissue-adapted invasion strategies of the rice blast fungus Magnaporthe oryzae. Plant Cell 22:31773187.

Milazzo, J., Pordel, A., Ravel, S., and Tharreau, D. 2019. First scientific report of Pyricularia oryzae causing gray leaf spot disease on perennial ryegrass (Lolium perenne) in France. Plant Dis. 103:1024.

Mills, K. B., Madden, L. V., and Paul, P. A. 2020. Quantifying the effects of temperature and relative humidity on the development of wheat blast incited by the Lolium pathotype of Magnapothe oryzae. Plant Dis. 104:2622-2633.

Mills, K. B., Salgado, J. D., Cruz, C. D., Valent, B., Madden, L. V., and Paul, P. A. 2021. Comparing the temporal development of wheat spike blast epidemics in a region of Bolivia where the disease is endemic. Plant Dis. 105:96-107.

Moss, M. A., and Trevathan, L. E. 1987. Environmental conditions conducive to infection of ryegrass by Pyricularia grisea. Phytopathology 77:863-866.

Mottaleb, K. A., Singh, P. K., He, X., Hossain, A., Kruseman, G., and Erenstein, O. 2019. Alternative use of wheat land to implement a potential wheat holiday as wheat blast control: In search of feasible crops in Bangladesh. Land Use Policy 82:1-12.

Mottaleb, K. A., Singh, P. K., Sonder, K., Kruseman, G., Tiwari, T. P., Barma, N. C. D., Malaker, P. K., Braun, H.-J., and Erenstein, O. 2018. Threat of wheat blast to South Asia's food security: An ex-ante analysis. PLoS One 13:e0197555. 
Navia-Urrutia, M. 2020. Engineering the wheat genome to reduce the susceptibility to fungal and viral diseases. Ph.D. thesis. Kansas State University, Manhattan, KS.

Oliveira-Garcia, E., and Valent, B. 2015. How eukaryotic filamentous pathogens evade plant recognition. Cur. Opin. Microbiol. 26:92-101.

Orasen, G., Greco, R., Puja, E., Pozzi, C., and Stile, M. R. 2020. Blast resistance $R$ genes pyramiding in temperate japonica rice. Euphytica 216:40.

Orbach, M. J., Chumley, F. G., and Valent, B. 1996. Electrophoretic karyotypes of Magnaporthe grisea pathogens of diverse grasses. Mol. Plant-Microbe Interact. 9:261-271.

Pedersen, D. K., Kane, R. T., and Wilkinson, H. T. 2000. First report of gray leaf spot caused by Pyricularia grisea on Lolium perenne in Illinois. Plant Dis. 84:1151.

Peng, Z., Oliveira-Garcia, E., Lin, G., Hu, Y., Dalby, M., Migeon, P., Tang, H., Farman, M., Cook, D., White, F. F., Valent, B., and Liu, S. 2019. Effector gene reshuffling involves dispensable mini-chromosomes in the wheat blast fungus. PLoS Genet. 15:e1008272.

Perelló, A., Martinez, L., and Molina, M. 2015. First report of virulence and effects of Magnaporthe oryzae isolates causing wheat blast in Argentina. Plant Dis. 99:1177-1178.

Pieck, M. L., Ruck, A., Farman, M. L., Peterson, G. L., Stack, J. P., Valent, B., and Pedley, K. F. 2017. Genomics-based marker discovery and diagnostic assay development for wheat blast. Plant Dis. 101:103-109.

Pizolotto, C. A., Maciel, J. L. N., Fernandes, J. M. C., and Boller, W. 2019. Saprotrophic survival of Magnaporthe oryzae in infested wheat residues. Eur. J. Plant Pathol. 153: 327-339.

Raveloson, H., Ratsimiala Ramonta, I., Tharreau, D., and Sester, M. 2018. Long-term survival of blast pathogen in infected rice residues as major source of primary inoculum in high altitude upland ecology. Plant Pathol. 67:610-618.

Rodrigues, F. Á., Rios, J. A., Debona, D., and Aucique-Pérez, C. E. 2017. Pyricularia oryzae-wheat interaction: Physiological changes and disease management using mineral nutrition and fungicides. Trop. Plant Pathol. 42:223-229.

Roy, K. K., Muzahid, E. R., Reza, M. A., Mustarin, K. E., Malaker, P. K., Barma, N. C. D., Hossain, I., He, X., and Singh, P. K. 2020. First report of triticale blast caused by the fungus Magnaporthe oryzae pathotype Triticum in Bangladesh. Can. J. Plant Pathol. https://www.doi.org/10.1080/07060661.2020.1793223.

Rush, M. C., and Carver, R. B. 1973. Ryegrass blast: A serious new disease in Louisiana. La. Agric. 16:15.

Sesma, A., and Osbourn, A. E. 2004. The rice blast leaf pathogen undergoes developmental processes typical of root-infecting fungi. Nature 431:582-586.

Silva, S. R., Custódio, A. A. P., Foloni, J. S. S., Betioli-Junior, E., and Bassoi, M. C. 2019. Nitrogen fertilization effects on wheat blast epidemics under varying field environmental conditions. Trop. Plant Pathol. 44:258-267.

Stack, J. P., Bostock, R. M., Hammerschmidt, R., Jones, J. B., and Luke, E. 2014. The National Plant Diagnostic Network: Partnering to protect plant systems. Plant Dis. 98:708-715.

Takan, J. P., Chipili, J., Muthumeenakshi, S., Talbot, N. J., Manyasa, E. O., Bandyopadhyay, R., Sere, Y., Nutsugah, S. K., Talhinhas, P., Hossain, M., Brown, A. E., and Sreenivasaprasad, S. 2012. Magnaporthe oryzae populations adapted to finger millet and rice exhibit distinctive patterns of genetic diversity, sexuality and host interaction. Mol. Biotechnol. 50:145-158.

Tembo, B., Mulenga, R. M., Sichilima, S., M’siska, K. K., Mwale, M., Chikoti, P. C., Singh, P. K., He, X., Pedley, K. F., Peterson, G. L., Singh, R. P., and Braun, H. J. 2020. Detection and characterization of fungus (Magnaporthe oryzae pathotype Triticum) causing wheat blast disease on rain-fed grown wheat (Triticum aestivum L.) in Zambia. PLoS One 15:e0238724.

Thierry, M., Gladieux, P., Fournier, E., Tharreau, D., and Ioos, R. 2020. A genomic approach to develop a new qPCR test enabling detection of the Pyricularia oryzae lineage causing wheat blast. Plant Dis. 104:60-70.

Tosa, Y., Inoue, Y., Trinh, T. P. V., and Chuma, I. 2016. Genetic and molecular analyses of the incompatibility between Lolium isolates of Pyricularia oryzae and wheat. Physiol. Mol. Plant Pathol. 95:84-86.

Tosa, Y., Hirata, K., Tamba, H., Nakagawa, S., Chuma, I., Isobe, C., Osue, J., Urashima, A. S., Don, L. D., Kusaba, M., Nakayashiki, H., Tanaka, A., Tani, T., Mori, N., and Mayama, S. 2004. Genetic constitution and pathogenicity of Lolium isolates of Magnaporthe oryzae in comparison with host species-specific pathotypes of the blast fungus. Phytopathology 94:454-462.

Tredway, L. P., Stevenson, K. L., and Burpee, L. L. 2005. Genetic structure of Magnaporthe grisea populations associated with St. Augustinegrass and tall fescue in Georgia. Phytopathology 95:463-471. 
Twidwell, E., Williams, G., Simmons, J. D., Alison, M. W., and Hutchison, C. F. 2019. Cool season pasture and forage varieties. Publication 2334. Louisiana State University Agricultural Center Extension, Baton Rouge, LA. https:/www.lsuagcenter.com/profiles/ bneely/articles/page1566411416349 (accessed January 31, 2021).

USDA Economic Research Service. 2020. https://www.ers.usda.gov/topics/crops/wheat/.

USDA National Agricultural Statistics Service. 2020. https://www.nass.usda.gov/Statistics by_Subject/result.php?321B1DA9-789A-3380-9D75-807ACCF6BEC8\&sector=CROPS\& group $=$ FIELD $\% 20$ CROPS\& comm $=$ WHEAT.

Urashima, A. S., Igarashi, S., and Kato, H. 1993. Host range, mating type and fertility of Pyricularia grisea from wheat in Brazil. Plant Dis. 77:1211-1216.

Urashima, A. S., Leite, S. F., and Galbieri, R. 2007. Efficiency of aerial dissemination of Pyricularia grisea. Summa Phytopathol. 33:275-279.

Urashima, A. S., Lavorent, N. A., Goulart, A. C. P., and Mehta, Y. R. 2004a. Resistance spectra of wheat cultivars and virulence diversity of Magnaporthe grisea isolates in Brazil. Fitopathol. Bras. 29:511-518.

Urashima, A. S., Alves, A. F., Silva, F. N., Oliveira, D., and Gazaffi, R. 2017. Host range, mating type and population structure of Magnaporthe sp. of a single barley field in São Paulo state, Brazil. J. Phytopathol. 165:414-424.

Urashima, A. S., Martins, T. D., Bueno, C. R. N. C., Favaro, D. B., Arruda, M. A., and Mehta, Y. R. 2004b. Triticale and barley: New hosts of Magnaporthe grisea in Sao Paulo, Brazil-Relationship with blast of rice and wheat. Pages 251-260 in: Rice Blast: Interaction with Rice and Control. S. Kawasaki, ed. Kluwer Academic Publishers, Dordrecht, Netherlands.

Urashima, A. S., Grosso, C., Stabili, A., Freitas, E., Silva, D., Netto, D., Franco, I., and Bottan, M. 2009. Effect of Magnaporthe grisea on seed germination, yield and quality of wheat. Pages 267-277 in: Advances in Genetic, Genomics and Control of Rice Blast Disease. G.-L. Wang and B. Valent, eds. Springer, Netherlands.

Valent, B., Farrall, L., and Chumley, F. G. 1991. Magnaporthe grisea genes for pathogenicity and virulence identified through a series of backcrosses. Genetics 127:87-101.

Valent, B., Singh, P. K., He, X., Farman, M., Tosa, Y., and Braun, H. J. 2020. Blast diseases: Evolution and challenges of a staple food crop fungal pathogen. Pages 267-292 in: Emerging Plant Diseases and Global Food Security. J. B. Ristaino and A. Records, eds. American Phytopathological Society Press, St. Paul, MN.

Valent, B., Farman, M., Tosa, Y., Begerow, D., Fournier, E., Gladieux, P., Islam, M. T., Kamoun, S., Kemler, M., Kohn, L. M., Lebrun, M.-H., Stajich, J. E., Talbot, N. J., Terauchi, R., Tharreau, D., and Zhang, N. 2019. Pyricularia graminis-tritici is not the correct species name for the wheat blast fungus: Response to Ceresini et al. (MPP 20:2). Mol. Plant Pathol. 20:173-179.

Viji, G., Wu, B., Kang, S., Uddin, W., and Huff, D. R. 2001. Pyricularia grisea causing gray leaf spot of perennial ryegrass turf: Population structure and host specificity. Plant Dis. 85:817-826.

Wang, B. H., Ebbole, D. J., and Wang, Z. H. 2017. The arms race between Magnaporthe oryzae and rice: Diversity and interaction of $A v r$ and $R$ genes. J. Integr. Agric. 16:27462760.

Wang, G.-L., and Valent, B., eds. 2009. Advances in Genetics, Genomics and Control of Rice Blast Disease. Springer Science and Business Media, New York, NY.

Wang, S., Asuke, S., Vy, T. T. P., Inoue, Y., Chuma, I., Win, J., Kato, K., and Tosa, Y. 2018. A new resistance gene in combination with $R m g 8$ confers strong resistance against Triticum isolates of Pyricularia oryzae in a common wheat landrace. Phytopathology 108:1299-1306.

Wang, X., Jia, Y., Wamishe, Y., Jia, M. H., and Valent, B. 2017. Dynamic changes in the rice blast population in the USA over six decades. Mol. Plant-Microbe Interact. 30:803812.

Williams, D. W., Burrus, P. B., and Vincelli, P. 2001. Severity of gray leaf spot in perennial ryegrass as influenced by mowing height and nitrogen level. Crop Sci. 41:1207-1211.

Wilson, R. A., and Talbot, N. J. 2009. Under pressure: Investigating the biology of plant infection by Magnaporthe oryzae. Nat. Rev. Microbiol. 7:185-195.

Wong, F. 2006. Gray leaf spot in the West: A new disease of perennial ryegrass and kikuyugrass has become established in California and Nevada. Golf Course Manage. 74:97-101.

Xue, L. H., Liu, Y., Li, C. J., and Wu, W. X. 2017. First report of gray leaf spot (Pyricularia oryzae) on Italian ryegrass (Lolium multiflorum) in China. Plant Dis. 101:1049.

Yaegashi, H., and Udagawa, S. 1978. Taxonomical identity of perfect state of Pyricularia grisea and its allies. Can. J. Bot.-Rev. Can. Bot. 56:180-183. 
Yasuhara-Bell, J., Pedley, K. F., Farman, M., Valent, B., and Stack, J. P. 2018. Specific detection of the wheat blast pathogen (Magnaporthe oryzae Triticum) by loop-mediated isothermal amplification. Plant Dis. 102:2550-2559.

Yasuhara-Bell, J., Pieck, M. L., Ruck, A., Farman, M. L., Peterson, G. L., Stack, J. P., Valent, B., and Pedley, K. F. 2019. A Response to Gupta et al. (2019) regarding the MoT3 Wheat Blast Diagnostic Assay. Phytopathology 109:509-511.

Zhang, H. L., Wu, Z. S., Wang, C. F., Li, Y., and Xu, J. R. 2014. Germination and infectivity of microconidia in the rice blast fungus Magnaporthe oryzae. Nat. Comm. 5:4518.

Zhang, N., Cai, G., Price, D. C., Crouch, J. A., Gladieux, P., Hillman, B., Khang, C. H., LeBrun, M.-H., Lee, Y.-H., Luo, J., Qiu, H., Veltri, D., Wisecaver, J. H., Zhu, J., and Bhattacharya, D. 2018. Genome wide analysis of the transition to pathogenic lifestyles in Magnaporthales fungi. Sci. Rep. 8:5862.

Zhang, N., Luo, J., Rossman, A. Y., Aoki, T., Chuma, I., Crous, P. W., Dean, R., de Vries, R. P., Donofrio, N., Hyde, K. D., Lebrun, M.-H., Talbot, N. J., Tharreau, D., Tosa, Y., Valent, B., Wang, Z., and Xu, J.-R. 2016. Generic names in Magnaporthales. IMA Fungus 7:155-159.

\section{Infrastructure and Experts}

Research on MoT is active at two USDAAPHIS-approved Biosafety Level-3 (BSL-3) containment laboratory facilities in the United States. These are USDA-ARS BSL-3 Plant Pathogen greenhouse containment facilities in the FDWSRU in Ft. Detrick, MD, and a BSL-3 laboratory with growth chambers in the Biosecurity Research Institute (BRI) at KSU in Manhattan, KS. To provide wheat blast field testing capability in MoT endemic environments, a wheat blast screening platform was established in Bolivia in 2010 and remains active. This nursery is an international partnership led by KSU and the USDA-ARS FDWSRU together with ANAPO (Bolivia), Biotrigo Genetica (Brazil), and other U.S. and international collaborators. In Bolivia, wheat blast evaluation is performed under irrigated field conditions and in controlled environment conditions (greenhouse and growth chambers). Field experiments are carried out in two locations during the winter wheat season (April to August) and one location during the summer season (December to March), which optimizes data collection in a short period. A permanent culture collection for MoT and MoL strains was developed and is maintained at Ft. Detrick by Gary Peterson, USDA-ARS FDWSRU.

The following Blast Integrated Project (USDA NIFA award \#2013-6800420378) team members have direct experience working with MoT in BSL-3 containment laboratories in the United States and/or in the field in South America, as well as experience working with native MoL strains.

Giovana Cruppe - Applied wheat pathology; wheat blast biology and control; biosecurity research. Kansas State University, Department of Plant Pathology, Manhattan, KS

Tel: 785-532-1392, gicruppe@ksu.edu

Christian Cruz - Crop biosecurity; quantitative epidemiology; crop physiology; remote sensing, machine learning, image processing, and sensorbased technology. Department of Botany \& Plant Pathology, Purdue University, West Lafayette, IN

Tel: 765-494-1515,cd-cruz@purdue.edu

Erick De Wolf - Epidemiology and Extension specialist; disease prediction models. Kansas State University, Department of Plant Pathology, Manhattan, KS Tel: 785-532-3968, dewolf1@ksu.edu

Mark Farman - Fungal genetics and genomics of M. oryzae on rice, wheat, and turf grasses. University of Kentucky, Department of Plant Pathology, Lexington, KY

Tel: 859-218-0728, mark.farman@uky.edu

Pierce A. Paul - Epidemiologist; field crops Extension specialist; disease forecasting; integrated management. The Ohio State University, Department of Plant Pathology, Wooster, OH

Tel: 330-263-3838,paul.661@osu.edu 
Kerry F. Pedley - Molecular biologist specializing in exotic fungal pathogens; development of molecular markers and PCR-based assays for discrimination and detection of foreign pathogens. USDA/ARS/Foreign Disease-Weed Science Research Unit, Fort Detrick, MD

Tel: 301-619-1668, kerry.pedley@usda.gov

Gary L. Peterson - Research biologist focusing on non-endemic wheat pathogens; evaluation of U.S. and International germplasm for blast resistance; Operational Committee of the International Wheat Blast Consortium, project \#8044-22000-046-04-N. USDA/ARS/Foreign Disease-Weed Science Research Unit, Fort Detrick, MD

Tel: 301-619-7313, gary.peterson@usda.gov

James P. Stack - Plant biosecurity and Extension specialist; Director of the Great Plains Diagnostic Network, Kansas State University, Department of Plant Pathology, Manhattan, KS

Tel: 785-532-1388, jstack@ksu.edu

Barbara Valent - Over 40 years' experience with M. oryzae, including wheat blast research in the late 1980s. Fungal pathogenicity and host specificity; fungal genome dynamics; disease control; Project Director for the NIFA-funded wheat blast projects. Kansas State University, Department of Plant Pathology, Manhattan, KS

Tel: 785-532-2336, bvalent@ksu.edu

\section{Web Resources}

If web page addresses have changed since the time of publication, please contact the appropriate topic experts and/or state contacts (see Infrastructure and Experts) for further information.

Wheat Disease Identification, from Kansas State University

https://bookstore.ksre.ksu.edu/pubs/MF2994.pdf

Small Grain Treatment Guide, from Montana State University https://store.msuextension.org/publications/AgandNaturalResources/MT199608 AG.pdf

NCERA184: Management of Small Grain Diseases

https://www.nimss.org/projects/view/mrp/outline/18343

WERA97: Diseases of Cereals

https://www.nimss.org/projects/view/mrp/outline/17297

Wheat Blast Web Page

https://www.k-state.edu/wheatblast/

National Plant Diagnostic Network

https://www.npdn.org/

Great Plains Diagnostic Network

https://www.npdn.org/gpdn/

Environmental Protection Agency-FIFRA Section 18 Pesticide Emergency

Exemptions

https://www.epa.gov/pesticide-registration/pesticide-emergency-

exemptions\#intro 